\title{
A systematic review of the effectiveness of taxes on nonalcoholic beverages and high-in-fat foods as a means to prevent obesity trends
}

This article was published in the following Dove Press journal:

ClinicoEconomics and Outcomes Research

18 October 2013

Number of times this article has been viewed

\author{
Nikolaos Maniadakis' \\ Vasiliki Kapaki ${ }^{1,2}$ \\ Louiza Damianidi ${ }^{3}$ \\ Georgia Kourlaba ${ }^{4}$ \\ 'Department of Health Services \\ Organization and Management, \\ National School of Public Health, \\ Athens, ${ }^{2}$ University of Peloponnese, \\ Peloponnese, ${ }^{3}$ Department of Allergy, \\ Second Pediatric Clinic, National \\ and Kapodistrian University of Athens \\ School of Medicine, Athens, ${ }^{4}$ The \\ Stavros Niarchos Foundation - \\ Collaborative Center for Clinical \\ Epidemiology and Outcomes \\ Research (CLEO), First and Second \\ Departments of Pediatrics, National \\ and Kapodistrian University of Athens \\ School of Medicine, Athens, Greece
}

Correspondence: Nikolaos Maniadakis Department of Health Services Organization and Management, National School of Public Health, 196 Alexandras Avenue,

Athens II 5 2I, Greece

Tel +30213201 0194

Fax +30 210 6433980

Email nmaniadakis@esdy.edu.gr
Background: As part of the efforts to curb obesity, a new focus seems to be put on taxing foods that are perceived as being associated with obesity (eg, sugar-sweetened beverages and foods high in fat, sugar, and salt content) as a policy instrument to promote healthier diets.

Objective: To assess the possible effects of such taxation policies by identifying and analyzing all studies which investigate the impact of price increases on consumption, caloric intake, or weight outcomes.

Methods: Electronic data bases were searched with appropriate terms and their combinations. Thereafter, abstracts were reviewed and studies were selected based on predefined criteria. The characteristics of the selected studies and the results were extracted in a special form and consequently were reviewed and synthesized.

Results: Price increase may lead to a reduction in consumption of the targeted products, but the subsequent effect on caloric intake may be much smaller. Only a limited number of the identified studies reported weight outcomes, most of which are either insignificant or very small in magnitude to make any improvement in public health.

Conclusion: The effectiveness of a taxation policy to curb obesity is doubtful and available evidence in most studies is not very straightforward due to the multiple complexities in consumer behavior and the underling substitution effects. There is need to investigate in-depth the potential underlying mechanisms and the relationship between price-increase policies, obesity, and public health outcomes.

Keywords: price, fat tax, sugar-sweetened beverages, calorie(s), elasticity, weight, body mass index

\section{Introduction}

Obesity prevalence is increasing worldwide, affecting both developed and developing countries. The prevalence of overweight and obese adults was estimated at 1.5 billion globally in 2008 by the World Health Organization, and this figure is projected to reach 2.3 billion by $2015 .{ }^{1}$ There is accumulated scientific evidence indicating that obesity is strongly related to a vast number of diseases, including hypertension, hypercholesterolemia, type 2 diabetes mellitus, respiratory conditions, arthritis, and certain types of cancer. Moreover, obesity reduces the quality of life of individuals. ${ }^{2}$

Along with morbidity and mortality, obesity also imposes a great economic burden upon society, which stems from the resources expended in the health care system to manage it, the expenditures incurred by sufferers and their families to cope with its consequences, and also the lost production caused by informal care, premature death, and inability to work. ${ }^{2}$ Several studies in European countries estimate the health 
care-related costs of obesity at $1.7 \%-3.0 \%$ of total health expenditure, ${ }^{3}$ while in the USA, it has been estimated that obesity accounts for almost $5 \%-10 \%$ of the total health care expenditure. ${ }^{4}$ At the individual level, studies indicate that an obese person incurs health care expenditures at least $25 \%$ higher than those of a normal-weight person. ${ }^{5,6}$ On the other hand, indirect cost, ie, increased production as a result of a health condition, is also significant. Notably, employers in some countries often pay higher insurance premiums for employees who are obese in comparison to employees who are not. ${ }^{7}$ In this context, some studies have also shown that obesity is associated with lower wages and lower household income. ${ }^{8,9}$ In this light, obesity constitutes a growing public health problem and concern throughout the world. Therefore, strategies aiming to prevent obesity are of paramount importance for both health and economic reasons.

Several factors have been linked to obesity, including socioeconomic, environmental, behavioral, and genetic. Total energy intake increase in conjunction with physical activity decrease has been indicated as a contributor to the obesity trend. ${ }^{10}$ In this context, it has been argued that overconsumption of sugar-sweetened beverages (SSBs) and high-in-fat, salt, and sugar foods (HFSSFs) may be associated with excess caloric intake and eventually increases in body weight. ${ }^{11,12}$ Thus, some authors suggest that mediating consumption of SSBs and HFSSFs in populations that exhibit relatively excess consumption rates could prove an effective intervention in reducing subsequently obesity rates. ${ }^{10}$ In this context, taxes on HFSSFs and SSBs, often called "fat or sugar taxes," have been introduced or are being considered in several countries as a means to regulate the consumption of these products and eventually to curb obesity, to trim health care costs, to raise revenue, and ultimately improve public health. ${ }^{13}$ On the other hand, a number of countries have abandoned the policy route of taxing foods either by abolishing existing taxes, eg, Denmark and the Netherlands, or by shelving respective ideas, eg, Italy. ${ }^{14}$

In any case, such taxes have provoked considerable controversy among the various stakeholders: the government, academic, scientific, health, and medical communities, consumers and their associations, and the food industry. Based on economic theory, the main rationale underpinning the adoption of such policies is that a tax and price increase on the targeted products may avert consumers from their consumption and divert them to healthier alternatives, and in this way there may be improvements in diet quality, weight status, and health outcomes in the long-term. Supporters of the fat taxation often also emphasize its signaling power to the food industry and consumers and its efficiency in raising revenue. ${ }^{15}$

On the other hand, opponents of such taxes argue that there are many factors which make such policies ineffective and even detrimental in certain circumstances. ${ }^{16}$ Firstly, interventions of these kinds of taxes/policies represent a violation of consumer sovereignty, ie, the freedom of individuals to choose freely for themselves in order to satisfy their needs. Regardless, it is difficult to attain the desired results because consumer behavior is complex and multifactorial and there are notable substitution effects which make the reduction in total energy intake by specific taxes unattainable. Taxes are also regressive in nature and the burden is proportionally higher on lower-income households, which generates significant equity concerns. Also, the approach presumes well-informed and price-sensitive consumers, which is not always the case, and hence there is a market failure that makes the specific policy ineffective. Therefore, many commentators argue that the aim of improving public health is unquestionably important, but taxes may not be the most appropriate policy measure to attain it. ${ }^{13}$

Hence, given the controversy around this issue, a systematic review was undertaken to synthesize the results of original studies examining the possible impact of tax policies and price increases upon the consumption of SSBs and HFSSFs and eventually upon caloric intake, weight, and outcomes in order to provide useful insights for decision makers and other stakeholders nationally and internationally.

\section{Methods}

\section{Search strategy}

Research papers were identified through web-based searches in PubMed, Web of Science, Cochrane Library, AgEcon, EconLit, and the National Agricultural Library databases and searches in other potentially relevant internet sources such as Google ${ }^{\circledR}$. Searching in the aforementioned bibliographical databases was conducted in the title and abstract on grounds of all potential combinations of three groups of terms presented in Figure 1. The reference lists of all relevant papers originally selected for inclusion in the review and relevant reviews were also searched manually to identify potentially relevant articles which were not identified by the original electronic search. The search spanned from 1990 to February 2013. The stated aim of this fiscal measure was not only to offset this price imbalance but also - as is often the case with excise taxation - to raise revenue, in particular to collect resources to be invested in nutrition programs. ${ }^{17,18}$ 


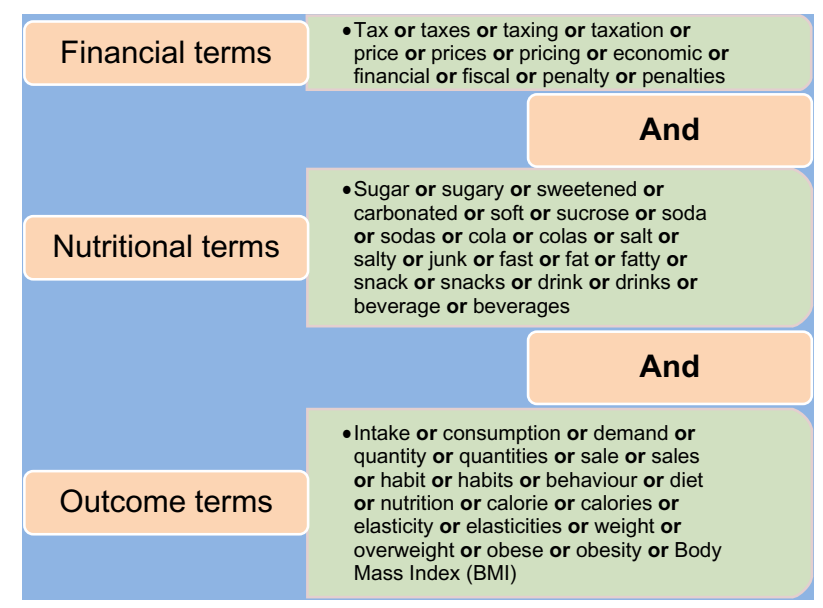

Figure I Search terms utilized.

\section{Study selection and data extraction}

Following the literature search, identified studies were checked to exclude duplicates. The remaining articles were independently screened by two researchers to identify studies that met the predetermined inclusion criteria. Original studies including the four types of primary research methods - existing data, experiments, surveys, and observation - that focused on the association between SSBs and HFSSFs prices and taxes and their corresponding consumption or energy intake or obesity-related outcomes were included in the present systematic review. On the other hand, systematic reviews, meta-analyses, qualitative studies, case studies, case reports, and letters to the editor were excluded. Moreover, only studies published in English with available full text and studies concerning human subjects were included.

The studies were selected following specific methodologically driven steps. Firstly, all identified studies were imported electronically into EndNote ${ }^{\circledR}$ bibliographic database (Thomson Reuters, New York, NY, USA) and were evaluated on the basis of titles and/or abstracts against the prespecified eligibility criteria. A check for double entries among the selected studies was made to ensure that the list contained unique studies for review. Subsequently, study abstracts and titles were reviewed and those which were deemed irrelevant were excluded and reasons for exclusion were noted. Obviously, rejected studies were those clearly not relevant to the subject of investigation. Whenever the information provided in titles/abstracts was insufficient to reach a clear decision on inclusion or exclusion or when the titles/abstracts indicated that studies met the inclusion criteria, the full papers were retrieved to be further screened. In cases where the information reported in the full text continued to be insufficient to make a decision about inclusion, studies were excluded. Then, essential details and data of studies meeting the inclusion criteria were extracted by two researchers into a spreadsheet and were classified according to their design - demand modeling, cross-sectional, longitudinal, mathematical modeling, cohort retrospective, and experimental. The overall study selection process was also documented through a flow chart showing the number of studies/papers remaining at each stage, although a screening process to identify articles using the studies bibliography had been done. The review was based on the Preferred Reporting Items for Systematic Reviews and Meta-Analyses (PRISMA) criteria.

\section{Results}

The initial literature review identified 3,700 citations for screening. Of these, 3,250 were excluded on the basis of title/ abstract and 395 after screening the full paper. Subsequently, a total of 55 were finally included in the review (Figure 2).

In terms of geographical location, most of the studies were conducted in the USA $(n=40)$ and the remaining in the UK $(\mathrm{n}=2)$, Norway, Italy $(\mathrm{n}=2)$, Denmark, Germany, France, the Netherlands, Mexico ( $\mathrm{n}=2$ ), Brazil, Taiwan, Singapore, and Australia. In terms of methodologies utilized, there was significant variation in terms of the research designs applied. In particular, there were several demand studies $(\mathrm{n}=22)$, followed by longitudinal studies $(\mathrm{n}=11)$, cross-sectional studies $(n=11)$, modeling studies $(n=6)$, experimental studies $(n=4)$, and cohort studies $(n=1)$. The majority of the studies were mainly focused on estimating price elasticity of demand $(n=30)$, others mainly focused on the effects of imposing certain taxation $(n=18)$, and the remaining studies considered both elements $(n=8)$. Health-related food taxes

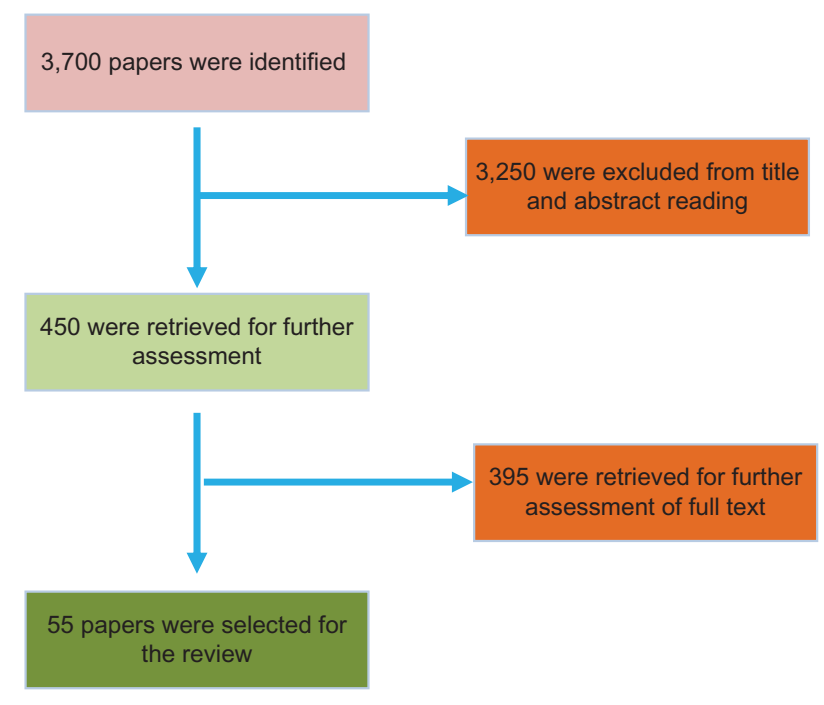

Figure 2 Flow chart of study selection. 
were either considered as excise or sales taxes. In terms of the targeted products, about half $(n=28)$ of the studies focused on SSBs only and the remaining $(n=36)$ either on HFSSFs alone or on HFSSFs in conjunction with SSBs.

In terms of the main outcomes considered, about half of the studies $(n=24)$ were concerned mainly with the effects of various interventions upon the consumption of products and the remaining $(\mathrm{n}=31)$ upon other outcomes such as energy intake and/or weight and/or body mass index (BMI). Notably, some studies reported results for all three outcomes of interest: energy intake, weight, and BMI.

The studies considered are presented in the Supplementary material. In particular, among the demand studies, nine presented the association between prices and taxes with the consumption of $\mathrm{SSBs}^{19-27}$ and three with the consumption of HFSSFs. ${ }^{28-30}$ These studies indicated that the price elasticity of demand for beverages is in the range of -0.5 to -1.6 depending on the beverage considered, with most of them falling below 1.0. This implies that the percentage changes in the quantities demanded were proportionally lower than the corresponding changes in prices. It should be noted that there was a lot of variation across the studies. There were also notable substitution effects detected between different products. The studies also pointed out that the negative effects on the consumption by price increases and taxes depend on factors such as the income group, and are more regressive towards the lowest income categories. Similar effects were found in the studies that focused on foods, also indicating a small or modest impact from price increase and taxes on the consumption of the targeted foods.

Moreover, six studies ${ }^{28,29,31-34}$ and five studies ${ }^{35-39}$ exam- $^{-}$ ined the association between beverage/food prices and taxes and energy and weight outcomes, respectively. These studies indicated that there is a very small impact of prices and taxes on energy intake and weight outcomes. These studies indicated that the caloric effect of a $10 \%$ increase in prices or a corresponding imposition of a tax reduces energy intake by a maximum of 50 calories per day, 450 per month, and up to 0.3 kilograms or 1.5 pounds per year, which cannot be considered significant. The specific studies also indicated the regressive nature of taxes and that their use is promoted mostly in order to generate revenue for the public purse.

Two studies assessed the effect of prices and taxes on the consumption of beverages and foods based on longitudinal studies. ${ }^{40,41}$ These studies indicated that the price elasticity of demand for beverages and foods is in the range of -0.05 to -0.35 depending on the beverage and food considered. Notably, the figures reported are much lower than those reported in demand studies. The findings in this group of studies also indicated that there are negative effects on consumption in most cases, which are more significant in certain groups, eg, overweight.

All studies investigated the effect of beverages/food prices or taxes with possible outcomes. For two studies, ${ }^{42,43}$ the outcome was energy intake, while for 16 studies, ${ }^{35-50}$ weight outcomes were considered. Elasticities were low and in some cases not significant, and results were heterogeneous and dependent on income, weight, sex, and age group. Notwithstanding the above, these studies indicated that there is a modest and insignificant impact from price increases and taxes on energy intake, weight, and BMI, which makes the authors argue that any taxes would have to be quite large to generate any meaningful effect. These studies also highlighted the regressive nature of taxes and that their usefulness is to mostly generate revenue.

Barquera et $\mathrm{al}^{51}$ and Claro et $\mathrm{al}^{52}$ examined the effect of prices on beverages consumption; Sturm and Datar ${ }^{53}$ examined the effect on food consumption only. However, elasticities on this occasion for beverages and foods were a bit contradictory. A Mexican and a Brazilian study derived elasticities for sodas to be about -1.0 , indicating that soda consumption is elastic whilst other beverages are in the inelastic range. By contrast, a USA study indicated that the elasticity of fast foods and soda in students is inelastic and effects of prices are inconsistent and marginal.

Moreover, six cross-sectional studies ${ }^{54-59}$ examined the association between prices and energy outcomes, while two other studies ${ }^{60,61}$ examined the association between prices and weight outcomes. The majority of the studies concluded that taxes are having trivial or modest effects on weight outcomes. These studies also indicated the regressive nature of taxes and that their use is mostly to generate revenue.

Some of the studies included in the review conducted behavioral experiments in the Netherlands, Taiwan, Singapore, and the USA. Particularly, four studies ${ }^{62-65}$ reported results on the effects of prices and taxes on the consumption and other outcomes of beverages and foods, respectively. Elasticities on this occasion between beverages and food were close to -1.0 , ie, the association is in the elastic range. The effect on caloric intake and weight outcomes was higher in other studies, assumedly due to much higher taxes in the range of $35 \%-50 \%$.

Finally, six of the 55 studies reviewed were modeling studies undertaken in the USA $(n=3), \operatorname{UK}(n=2)$, and Australia $(n=1)$. Two of them used cross-sectional data and the others were based on census data. 


\section{Discussion}

The current study presents the results of a literature review undertaken to establish whether the available evidence supports use of fat taxes as a means to improve weight and health outcomes. The existing literature fails to draw consistent and undisputed evidence on the effectiveness of pricing and tax policies to reduce obesity rates. The heterogeneity observed in the findings of the included studies could be partially explained by the significant heterogeneity in policy settings and study designs employed to investigate the issue. It is evident that price and tax increases on beverages and fatty foods may reduce their consumption. However, there is controversy as to whether this also may result in meaningful reductions in caloric intake and weight. The studies that show some positive impact of economic policies also indicate that any potential reductions in weight are statistically insignificant to trigger desired effects. Moreover, elasticities indicate that significant weight outcome effects may be reached with very large tax rates, which would, however, exacerbate equity concerns related to their adverse implications for low-income groups.

At this point it should be noted that there are several important factors - obesity prevalence, consumption levels, behavioral patterns, and baseline tax rate - that should be considered within local contexts when contemplating the potential benefits of taxation. ${ }^{66}$ When any of these factors shift, the potential impact of fat taxation becomes less certain and unpredictable. However, it is very difficult to estimate how a population would respond to a tax on certain foods. ${ }^{67}$ Some consumers may respond by reducing their consumption of fruits and vegetables in order to pay for the more expensive HFSSFs, thus defeating the purpose of the tax. Others may seek substitutes for the taxed products, which may have similar or even higher fat, sugar, or salt content than the taxed products originally consumed. Thus, although there may be a decrease in the purchasing of the taxed food, consumers may end up consuming the same or even more calories from other substitute foods or drinks. This is in accordance with the findings of many studies in the literature..$^{57,68-72}$

Moreover, to effectively apply policies to reduce consumption of high-calorie, high-fat, or high-carbohydrates foods, policy analysts need to disaggregate food-specific demand estimates according to socioeconomic status and assess the possible impacts of policy changes on food consumption and welfare outcomes at a more disaggregated level in addition to the total effects. This could be explained by the fact that the expenditure shared for food and consumption behaviors may differ significantly among different socioeconomic groups. ${ }^{73}$ The Organization for Economic Co-operation and Development in 2010 reported that the impact of fiscal measures aiming to change behaviors may be unpredictable; because the price elasticity of demand varies across individuals and population groups, these measures can bear more heavily on low-income groups than on those with higher incomes, and substitution effects are not always obvious. ${ }^{74}$ Further to considering the above, one needs to consider which products will be the targets of intervention.

Moreover, in regard to SSBs, the association between their consumption and overweight is a complex metabolic relationship and there are many behavioral and environmental factors that may be influencing beverage and food consumption and weight. Many of the food tax policies implemented are focusing on soft drinks as a number of influential reports assert that sugary drinks play a key role in the etiology of obesity. Contrary to this premise, a 2012 report from the National Center for Health Statistics, US Centers for Disease Control and Prevention examined data on consumption of added sugars among US children and adolescents and reported that added sugar from food (59\%) was higher than sugar from beverages (41\%). ${ }^{75}$ Moreover, research published in 2010 from Queen Margaret University, Edinburgh, UK, shows that SSBs consumed in moderate quantities do not promote short-term weight gain, do not trigger additional carbohydrate intake, and do not generate changes in the moods of overweight women. ${ }^{76}$ In 2007, there was a similar study performed on average-weight women and came out with similar conclusions. ${ }^{77}$ Hence, evidence suggests that the hypothetic contribution of SSBs on weight gain perhaps has been overestimated. ${ }^{78-80}$

Moreover, broader taxes on HFSSFs would possibly allow less substitution than narrow taxes. ${ }^{81}$ However, a concern with taxing a wide range of products would be the fact that people should be encouraged to consume a wide range of food and beverage products, eg, milk and olive oil, that would be difficult to include in the tax category. ${ }^{81}$ Furthermore, in some cases, taxing many food groups could possibly lead to nutrient deficiencies, in which case economic policies may have harmful nutritional and health effects. ${ }^{38,82}$

Based on the above, there is no doubt that a public health approach to develop population-based strategies for the prevention of excess weight gain is of great importance ${ }^{83,84}$ Some effective strategies involve changes to personal, environmental, and socioeconomic factors associated with obesity. A proposed framework by Sacks et a ${ }^{85}$ suggests that policy actions on the development and implementation of effective public health strategies on obesity prevention should (1) deal with the food environments, the physical activity environments, and the 
broader socioeconomic environments; (2) directly influence behavior, aiming at improving eating and physical activity behaviors; and (3) support health services and clinical interventions. There are abundant examples of the effectiveness of such measures. ${ }^{85-95}$ Lastly, a number of barriers to an effective obesity management program have been identified in the literature that policy makers need to be aware of in order to address them adequately. ${ }^{96-107}$ However, the development and implementation of obesity prevention strategies should target those factors that can effectively control obesity.

For instance, in Greece it is proven that obesity is a growing health problem and concern. However, there is accumulating evidence indicating that SSBs may not be a determinant of obesity in Greece. For instance, a 2006 study examined energy intake, energy expenditure, diet composition, and obesity of adolescents in northern Greece, and showed that cola drink consumption did not significantly differ between overweight and non-overweight adolescents. ${ }^{108}$ Additionally, in another recent study in children aged 10-12 years old, it was found that although Spain and Greece had the highest obesity rates among the European countries examined, they also had the lowest soft drink daily consumption. ${ }^{109}$ It is important to note, however, that Greek children had lower physical activity levels and were reported to skip breakfast more often than their counterparts in other countries. ${ }^{109}$ Finally, the European Prospective Investigation into Cancer and Nutrition (EPIC) study showed that Greek adults over 35 years have the lowest consumption of sugar among the European countries that participated in the research program. Additionally, in the same study, it was also shown that nonalcoholic and carbonated drinks contribute a minor percentage of total carbohydrate daily intake - indicatively $2.8 \%$ of total carbohydrate intake in men and $1.8 \%$ of total carbohydrate intake in women - and an even lower percentage of total energy daily intake. ${ }^{10}$ The above data suggest that soft drink consumption may be a minor contributor to energy and carbohydrate intake in Greece in children, adolescents, and adults. The high obesity phenomenon in Greece is probably due to excess fat consumption in combination with lack of exercise. Therefore, targeting SSBs for obesity management or prevention in Greece is not an effective approach to curtailing obesity epidemic trends. Proper policies and interventions need to be designed based on the grounds of this local evidence.

The results of this review must be interpreted cautiously. First of all, in many studies, transformation of consumption figures to energy and weight outcomes was often based on extrapolation models, which require careful consideration. Caution must be directed to the model that is used to translate energy intake changes to weight changes. Using static weight models may provide quite different estimates in comparison to dynamic weight models. Static models generate a linear reduction in body weight over time, based on the assumption that every pound in weight reduction accounts for almost 3,500 calories, which is an assumption that has been challenged in the literature, and if not true undermines many findings. On the other hand, dynamic models account for the effects of weight loss by assuming changes in energy requirements due to weight reduction and fat and lean mass proportion, but they also involve various assumptions. ${ }^{35}$ Secondly, when weight outcomes in certain studies are obtained directly and not through modeling, it is important to consider whether the measurements were obtained with objective assessments or were based on self-reporting.

Thirdly, in regards to the estimation of caloric intake effects, it is important to consider whether any potential changes are referring to energy intake related to the targeted product taxed or to the total energy intake in general. Due to the substitution effects, the total outcome is far more interesting from a policy perspective. Additionally, when total energy intake is considered, it is essential to clarify how it was estimated and whether possible substitution was taken into account as there are strong substitution dynamics between different foods. For instance, a soft drink tax may lead to reduction in calories due to consumption of soft drinks, but this reduction may be completely offset by the increase in the consumption of milk. ${ }^{56}$

Last but not least, in some studies, the populations investigated were not representative or adequately described and the studies have been undertaken in specific settings, which are difficult to extrapolate to European populations and policy environments in light of the fact that results are dependent on population behavioral aspects.

\section{Conclusion}

The systematic review of the literature demonstrated that the effect of price and tax increase upon the consumption of SSBs and HFSSFs and eventually upon caloric intake and obesity-related outcomes is controversial. To be more precise, there is strong evidence that such measures influence the consumption of SSBs and HFSSFs, but there is no significant effect on obesity-related outcomes, ie, weight, BMI, and obesity. Thus, more research is needed in this area to gain better insights on the use of economic policies aimed at addressing obesity trends, especially from a European perspective. Moreover, when considering environmental, socioeconomic, and genetic contributors to obesity, it is advisable that policies focus first on 
cognitive behavioral changes and then on environmental factors. Such policies would create conscious people who are aware of the obesity problem and the main cause of weight gain, which is energy imbalance, and also its possible solutions, including encumbrances due to genetic or habitual factors.

\section{Acknowledgment}

This work was funded by Medical Consensus.

\section{Disclosure}

The authors report no conflicts of interest in this work.

\section{References}

1. Obesity and overweight: fact sheet no 311 [webpage on the Internet]. Geneva: World Health Organization; 2012 [cited Nov 2012). Available from: http://www.who.int/mediacentre/factsheets/fs311/en/index.html. Accessed August 13, 2013.

2. Sassi F. Obesity and the Economics of Prevention: Fit Not Fat. Paris: OECD Publishing; 2010. Available from: http://www.oecd.org/els/ health-systems/46044572.pdf. Accessed August 13, 2013.

3. Branca F, Nikogosian H, Lobstein T. The Challenge of Obesity in the WHO European Region and the Strategies For Response. Geneva: World Health Organization; 2007. Available from: http://www.euro. who.int/_data/assets/pdf_file/0008/98243/E89858.pdf. Accessed August 13, 2013.

4. Tsai AG, Williamson DF, Glick HA. Direct medical cost of overweight and obesity in the USA: a quantitative systematic review. Obes Rev. 2011;12(1):50-61.

5. Withrow D, Alter DA. The economic burden of obesity worldwide: a systematic review of the direct costs of obesity. Obes Rev. 2011; 12(2):131-141.

6. Cawley J, Meyerhoefer C. The medical care costs of obesity: an instrumental variables approach. $J$ Health Econ. 2012;31(1):219-230.

7. Trogdon JG, Finkelstein EA, Hylands T, Dellea PS, Kamal-Bahl SJ. Indirect costs of obesity: a review of the current literature. Obes Rev. 2008;9(5):489-500.

8. Lehnert T, Sonntag D, Konnopka A, Reidel-Heller S, Konig H. Economic costs of overweight and obesity. Best Pract Res Clin Endocrinol Metab. 2013;27(2):105-115.

9. Hojgaard B, Olsen KR, Sogaard J, Sorenson TI, Gyrd-Hansen D. Economic costs of abdominal obesity. Obes Facts. 2008;1(3):146-154.

10. Malik VS, Willett WC, Hu FB. Global obesity: trends, risk factors, and policy implications. Nat Rev Endocrinol. 2013;9(1):13-27.

11. Vartanian LR, Schwartz MB, Brownell KD. Effects of soft drink consumption on nutrition and health: a systematic review and meta-analysis. Am J Public Health. 2007;97(4):667-675.

12. Malik VS, Schulze MB, Hu FB. Intake of sugar-sweetened beverages and weight gain: a systematic review. Am J Clin Nutr. 2006;84(2): 274-288.

13. Mytton OT, Clarke D, Rayner M. Taxing unhealthy food and drinks to improve health. BMJ. 2012;344:e2931.

14. Bomsdorf C. Denmark scraps much-aligned "fat tax" after a year. The Wall Street Journal. November 11, 2012;Sect A:12.

15. Leigh S. "Twinkie tax" worth a try in fight against obesity. U SA Today. December 2, 2004; Sect A:13.

16. Cash SB, Sunding DL, Zilberman D. Fat taxes and thin subsidies: prices, diet, and health outcomes. Acta Agriculturae Scandinavica Section CFood Economics. 2005;2:167-174.

17. Brownell KD, Farley T, Willett WC, et al. The public health and economic benefits of taxing sugar-sweetened beverages. $N$ Engl $J$ Med. 2009;361(16):1599-1605.
18. Leicester A, Windmeijer F. The "Fat Tax": Economic Incentives To Reduce Obesity (Briefing Note 49). London: The Institute for Fiscal Studies; 2004. Available from: http://eprints.ucl.ac.uk/14931/1/14931. pdf. Accessed August 13, 2013.

19. Brown GM. Impact of income on price and income responses in the differential demand system. Journal of Agricultural and Applied Economics. 2008;40(2):593-608.

20. Brown MG, Jauregui CE. Conditional Demand System For Beverages. Gainesville, FL: Florida Department of Citrus; 2011. Available from: http://ageconsearch.umn.edu/bitstream/104335/2/RP\%202011-1.pdf. Accessed August 13, 2013.

21. Brown Mark G, Lee JY, Seale JL. Demand relationships among juice beverages: a differential demand system approach. Journal of Agricultural and Applied Economics. 1994;26(2):417-429.

22. Dharmasena S, Capps O Jr. Demand interrelationships of at home nonalcoholic beverage consumpion in the United States. Poster presented at: Agricultural and Applied Economics Association and American Council on Consumer Interests Joint Annual Meeting; July 28, 2009; Milwaukee, WI.

23. Dharmasena S, Capps O Jr. On taxing sugar-sweetened beverages to combat the obesity problem. Poster presented at: Agricultural and Applied Economics Association, Canadian Agricultural Economics Society, and Western Agricultural Economics Association Joint Annual Meeting; July 27, 2010; Denver, CO.

24. Gustavsen GW. Public policies and the demand for carbonated soft drinks: a censored quantile regression approach. Poster presented at: 11th Congress of the European Association of Agricultural Economists; August 23-27, 2005; Copenhagen, Denmark.

25. Pofahl GM, Capps O Jr, Clauson A. Demand for non-alcoholic beverages: evidence from the ACNielsen Home Scan Panel. Poster presented at: American Agricultural Economics Association Annual Meeting; July 24-27, 2005; Providence, RI.

26. Yen ST, Lin BH, Smallwood DM, Andrews M. Demand for nonalcoholic beverages: the case of low-income households. Agribusiness. 2004;20(3):309-321.

27. Zheng Y, Kaiser HM. Estimating assymetric advertising response: an application to US nonalcoholic beverage demand. Journal of Agricultural and Applied Economics. 2008;40(3):837-849.

28. Kuchler F, Tegene A, Harris JM. Taxing snack foods: manipulating diet quality or financing information programs? Applied Economic Perspectives and Policy. 2005;27(1):4-20.

29. Pieroni L, Lanari D, Salmasi L. Food prices and overweight patterns in Italy. Eur J Health Econ. 2013;14(1):133-151.

30. Zhen C, Wohlgenant MK, Karns S, Kaufman P. Habit formation and demand for sugar-sweetened beverages. Am J Agric Econ. 2010;93(1): 175-193.

31. Chouinard HH, Davis DE, LaFrance JT, Perloff JM. Fat taxes: big money for small change. Forum Health Econ Policy. 2007;10(2): $1558-9544$.

32. Dharmasena S, Capps O Jr. Intended and unintended consequences of a proposed national tax on sugar-sweetened beverages to combat the US obesity problem. Health Econ. 2012;21(6):669-694.

33. Gustavsen GW, Rickertsen K. The effects of taxes on purchases of sugar-sweetened carbonated soft drinks: a quantile regression approach. Appl Econ. 2011;43(6):707-716.

34. Senarath D, Davis GC, Capps O Jr. Partial versus general equilibrium calorie and revenue effects of a sugar-sweetened beverage tax. Poster presented at: Agricultural and Applied Economics Association and Northeastern Agricultural and Resource Economics Association Joint Annual Meeting; July 26, 2011; Pittsburgh, PA.

35. Lin BH, Smith TA, Lee JY, Hall KD. Measuring weight outcomes for obesity intervention strategies: the case of a sugar-sweetened beverage tax. Econ Hum Biol. 2011;9(4):329-341.

36. Meyerhoefer CD, Leibtag ES. A spoonful of sugar helps the medicine go down: the relationship between food prices and medical expenditures on diabetes. Am J Agric Econ. 2010;92(5):1271-1282. 
37. Smed S, Jensen JD, Denver S. Differentiated food taxes as a tool in health and nutrition policy. Poster presented at: 11th Congress of the European Association of Agricultural Economists; August 23-27, 2005; Copenhagen, Denmark.

38. Thiele S. Fat tax: a political measurement to reduce overweight? The case of Germany. Poster presented at: 1st Joint European Association of Agricultural Economists and Agricultural and Applied Economics Association Seminar; September 15-17, 2010; Freising-Weihenstephan, Germany.

39. Zhen M, Beghin JC, Jensen HH. Accounting for Product Substitution in the Analysis of Food Taxes Targeting Obesity. Ames, IA: Center for Agricultural and Rural Development; 2011. Available from: http:// www.card.iastate.edu/publications/dbs/pdffiles/10wp518.pdf. Accessed August 13, 2013.

40. Allais O, Bertail P, Nichele V. The effects of a "fat tax" on the nutrient intake of French households. Poster presented at: 12th Congress of the European Association of Agricultural Economists; August 26-29, 2008; Ghent, Belgium.

41. Gordon-Larsen P, Guilkey DK, Popkin BM. An economic analysis of community-level fast food prices and individual-level fast food intake: a longitudinal study. Health Place. 2011;17(6):1235-1241.

42. Khan LK, Sobush K, Keener D, et al. Recommended community strategies and measurements to prevent obesity in the United States. $M M W R$ Recomm Rep. 2009;58(RR-7):1-26.

43. Sturm R, Powell LM, Chriqui JF, Chaloupka FJ. Soda taxes, soft drink consumption, and children's body mass index. Health Aff (Millwood). 2010;29(5):1052-1058.

44. Auld CM, Powell LM. Economics of food energy density and adolescent body weight. Economica. 2009;76(304):719-740.

45. Duffey KJ, Gordon-Larsen P, Shikany JM, Guilkey D, Jacobs DR Jr, Popkin BM. Food price and diet and health outcomes: 20 years of the CARDIA Study. Arch Intern Med. 2010;170(5):420-426.

46. Finkelstein EA, Zhen C, Nonnemaker J, Todd JE. Impact of targeted beverage taxes on higher- and lower-income households. Arch Intern Med. 2010;170(22):2028-2034.

47. Powell LM. Fast food costs and adolescent body mass index: evidence from panel data. J Health Econ. 2009;28(5):963-970.

48. Powell LM, Chaloupka FJ. Food prices and obesity: evidence and policy implications for taxes and subsidies. Milbank Q. 2009;87(1):229-257.

49. Wendt M, Todd JE. The Effect of Food and Beverage Prices on Children's Weights. Washington, DC: US Department of Agriculture; 2011. Available from: http://www.ers.usda.gov/media/123670/err118.pdf. Accessed August 13, 2013.

50. Wendt M, Todd JE. Do low prices for sugar-sweetened beverages increase children's weights? Poster presented at: Agricultural and Applied Economics Association, Canadian Agricultural Economics Society, and Western Agricultural Economics Association Joint Annual Meeting; July 27, 2010; Denver, CO.

51. Barquera S, Hernandez-Barrera L, Tolentino ML, et al. Energy intake from beverages is increasing among Mexican adolescents and adults. J Nutr. 2008;138(12):2454-2461.

52. Claro RM, Levy RB, Popkin BM, Monteiro CA. Sugar-sweetened beverage taxes in Brazil. Am J Public Health. 2012;102(1):178-183.

53. Sturm R, Datar A. Regional price differences and food consumption frequency among elementary school children. Public Health. 2011;125(3):136-141.

54. Beydoun MA, Powell LM, Chen X, Wang Y. Food prices are associated with dietary quality, fast food consumption, and body mass index among US children and adolescents. J Nutr. 2011;141(2):304-311.

55. Fletcher JM, Frisvold D, Tefft N. Taxing soft drinks and restricting access to vending machines to curb child obesity. Health Aff (Millwood). 2010;29(5):1059-1066.

56. Fletcher JM, Frisvold D, Tefft N. Can soft drink taxes reduce population weight? Contemp Econ Policy. 2010;28(1):23-35.

57. Fletcher JM, Frisvold DE, Tefft N. The effects of soft drink taxes on child and adolescent consumption and weight outcomes. J Public Econ. 2010;94(11-12):967-974.
58. Powell LM, Zhao Z, Wang Y. Food prices and fruit and vegetable consumption among young American adults. Health Place. 2009;15(4): 1064-1070.

59. Wang YC, Coxson P, Shen YM, Goldman L, Bibbins-Domingo K. A penny-per-ounce tax on sugar-sweetened beverages would cut health and cost burdens of diabetes. Health Aff (Millwood). 2012;31(1): 199-207.

60. Arroyo P, Loria A, Mendez O. Changes in the household calorie supply during the 1994 economic crisis in Mexico and its implications on the obesity epidemic. Nutr Rev. 2004;62(7 Pt 2):S163-S168.

61. Beydoun MA, Powell LM, Wang Y. The association of fast food, fruit and vegetable prices with dietary intakes among US adults: is there modification by family income? Soc Sci Med. 2008;66(11):2218-2229.

62. Block JP, Chandra A, McManus KD, Willet WC. Point-of-purchase price and education intervention to reduce consumption of sugary soft drinks. Am J Public Health. 2010;100(8):1427-1433.

63. Epstein LH, Dearing KK, Roba LG, Finkelstein E. The influence of taxes and subsidies on energy purchased in an experimental purchasing study. Psychol Sci. 2010;21(3):406-414.

64. Nederkoorn C, Havermans RC, Giesen JC, Jansen A. High tax on high energy dense foods and its effects on the purchase of calories in a supermarket. An experiment. Appetite. 2011;56(3):760-765.

65. Yang CC, Chiou WB. Substitution of healthy for unhealthy beverages among college students. A health-concerns and behavioral-economics perspective. Appetite. 2010;54(3):512-516.

66. Jou J, Techakehakij W. International application of sugar-sweetened beverage (SSB) taxation in obesity reduction: factors that may influence policy effectiveness in country-specific contexts. Health Policy. 2012;107(1):83-90.

67. Hawkes C. Food taxes: what type of evidence is available to inform policy development? Nutr Bull. 2012;37(1):51-56.

68. Waterlander WE, Steenhuis IH, de Boer MR, Schuit AJ, Seidell JC. Introducing taxes, subsidies or both: the effects of various food pricing strategies in a web-based supermarket randomized trial. Prev Med. 2012;54(5):323-330.

69. Smith TA, Lin BH, Morrison RM. Taxing caloric sweetened beverages to curb obesity. Amber Waves. 2010;8(3):22-27.

70. de Castro JM. Genetic influences on daily intake and meal patterns of humans. Physiol Behav. 1993;53(4):777-782.

71. Hasselbalch AL. Genetics of dietary habits and obesity - a twin study. Dan Med Bull. 2010;57(9):B4182.

72. Bell CG, Walley AJ, Froguel P. The genetics of human obesity. Nat Rev Genet. 2005;6(3):221-234.

73. Amarasinghe A, D'Souza G. Obesity Prevention: A Review of the Interactions and Interventions, and some Policy Implications. Morgantown, WV: West Virginia University Regional Research Institute; 2010. Available from: http://rri.wvu.edu/wp-content/uploads/2012/11/wp2010-2_ Amarasinghe_DSouza_Obesity.pdf. Accessed August 13, 2013.

74. Organization for Economic Co-operation and Development. Healthy choices. Poster presented at: Organization for Economic Co-operation and Development Health Ministerial Meeting; October 7-8, 2010; Paris, France.

75. Ervin RB, Kit BK, Carroll MD, Ogden CL. Consumption of added sugar among US children and adolescents, 2005-2008. NCHS Data Brief. 2012;(87)1-8.

76. Reid M, Hammersley R, Hill AJ, Skidmore P. Long-term dietary compensation for added sugar: effects of supplementary sucrose drinks over a 4-week period. Br J Nutr. 2007;97(1):193-203.

77. Reid M, Hammersley R, Duffy M. Effects of sucrose drinks on macronutrient intake, body weight, and mood state in overweight women over 4 weeks. Appetite. 2010;55(1):130-136.

78. Forshee RA, Anderson PA, Storey ML. Sugar-sweetened beverages and body mass index in children and adolescents: a meta-analysis. $\mathrm{Am}$ J Clin Nutr. 2008;87(6):1662-1671.

79. Gibson S. Sugar-sweetened soft drinks and obesity: a systematic review of the evidence from observational studies and interventions. Nutr Res Rev. 2008;21(2):134-147. 
80. Barclay AW, Brand-Miller J. The Australian paradox: a substantial decline in sugars intake over the same timeframe that overweight and obesity have increased. Nutrients. 2011;3(4):491-504.

81. Fletcher J. Soda taxes and substitution effects: will obesity be affected? Choices. 2011;26(3).

82. Crowle JT, Turner E. Childhood Obesity: An Economic Perspective. Melbourne: Australian Government Productivity Commission: 2010.

83. World Health Organization. Obesity: Preventing and Managing the Global Epidemic. Technical Report Series 894. Geneva: World Health Organization; 2000.

84. Aranceta J, Morena B, Moya M, Anadon A. Prevention of overweight and obesity from a public health perspective. Nutr Rev. 2009;67(Suppl 1): S83-S88.

85. Sacks G, Swinburn B, Lawrence M. Obesity Policy Action framework and analysis grids for a comprehensive policy approach to reducing obesity. Obes Rev. 2009;10(1):76-86.

86. Swinburn B, Egger G. Preventive strategies against weight gain and obesity. Obes Rev. 2002;3(4):289-301.

87. Dietz WH, Benken DE, Hunter AS. Public health law and the prevention and control of obesity. Milbank Q. 2009;(8791):215-227.

88. Craven BM, Marlow ML, Shiers AF. Fat taxes and other interventions won't cure obesity. Economic Affairs. 2012;32(2):36-40.

89. Sallis JF, Glanz K. Physical activity and food environments: solutions to the obesity epidemic. Milbank Q. 2009;87(1):123-154.

90. Foster GD, Sherman S, Borradaile KE, et al. A policy-based school intervention to prevent overweight and obesity. Pediatrics. 2008;121(4): e794-e802.

91. van Zutphen M, Bell AC, Kremer PJ, Swinburn BA. Association between the family environment and television viewing in Australian children. J Paediatr Child Health. 2007;43(6):458-463.

92. Golan M, Weizman A. Familial approach to the treatment of childhood obesity: conceptual mode. J Nutr Educ. 2001;33(2):102-107.

93. Colby JJ, Elder JP, Peterson G, Knisley PM, Carleton RA. Promoting the selection of healthy food through menu item description in a familystyle restaurant. Am J Prev Med. 1987;3(3):171-177.

94. Winett RA, Wagner JL, Moore JF, et al. An experimental evaluation of a prototype public access nutrition information system for supermarkets. Health Psychol. 1991;10(1):75-78.

95. Chu C, Driscoll T, Dwyer S. The health-promoting workplace: an integrative perspective. Aust N ZJ Public Health. 1997;21(4 Spec No): 377-385.

96. Villagra VG. An obesity/cardiometabolic risk reduction disease management program: a population-based approach. Am J Med. 2009; 122(4 Suppl 1):S33-S36.

97. Frank A. A multidisciplinary approach to obesity management: the physician's role and team care alternatives. J Am Diet Assoc. 1998; 98(10 Suppl 2):S44-S48.
98. MacLean L, Edwards N, Garrard M, Sims-Jones N, Clinton K, Ashley L. Obesity, stigma and public health planning. Health Promot Int. 2009;24(1):88-93.

99. Villagra V. Strategies to control costs and quality: a focus on outcomes research for disease management. Med Care. 2004;42(Suppl 4): III24-III30

100. Alemanno A, Carreno I. Fat taxes in the European Union between fiscal austerity and the fight against obesity. European Journal of Risk Regulation. 2011;2(4):571-576.

101. Shields M, Tremblay MS. Sedentary behaviour and obesity. Health Rep. 2008;19(2):19-30.

102. Lajunen HR, Keski-Rahkonen A, Pulkkinen L, Rose RJ, Rissanen A, Kaprio J. Are computer and cell phone use associated with body mass index and overweight? A population study among twin adolescents. BMC Public Health. 2007;7:24.

103. Fotheringham MJ, Wonnacott RL, Owen N. Computer use and physical inactivity in young adults: public health perils and potentials of new information technologies. Ann Behav Med. 2000;22(4):269-275.

104. McDonald CM, Baylin A, Arsenault JE, Mora-Plazas M, Villamor E. Overweight is more prevalent than stunting and is associated with socioeconomic status, maternal obesity, and a snacking dietary pattern in school children from Bogota, Colombia. J Nutr. 2009;139(2): 370-376.

105. Berteus Forslund H, Torgerson JS, Sjostrom L, Lindroos AK. Snacking frequency in relation to energy intake and food choices in obese men and women compared to a reference population. Int J Obes (Lond). 2005;29(6):711-719.

106. Block JP, He Y, Zaslavsky AM, Ding L, Ayanian JZ. Psychosocial stress and change in weight among US adults. Am J Epidemiol. 2009;170(2):181-192.

107. De Vriendt T, Moreno LA, De Henauw S. Chronic stress and obesity in adolescents: scientific evidence and methodological issues for epidemiological research. Nutr Metab Cardiovasc Dis. 2009;19(7): 511-519

108. Hassapidou M, Fotiadou E, Maglara E, Papadopoulou SK. Energy intake, diet composition, energy expenditure, and body fatness of adolescents in northern Greece. Obesity (Silver Spring). 2006;14(5): 855-862.

109. Brug J, van Stralen MM, Te Velde SJ, et al. Differences in weight status and energy-balance related behaviors among schoolchildren across Europe: the ENERGY project. PLoS One. 2012;7(4):e34742.

110. von Ruesten A, Steffen A, Floegel A, et al. Trend in obesity prevalence in European adult cohort populations during follow-up since 1996 and their predictions to 2015. PLoS One. 2011;6(11):e27455. 


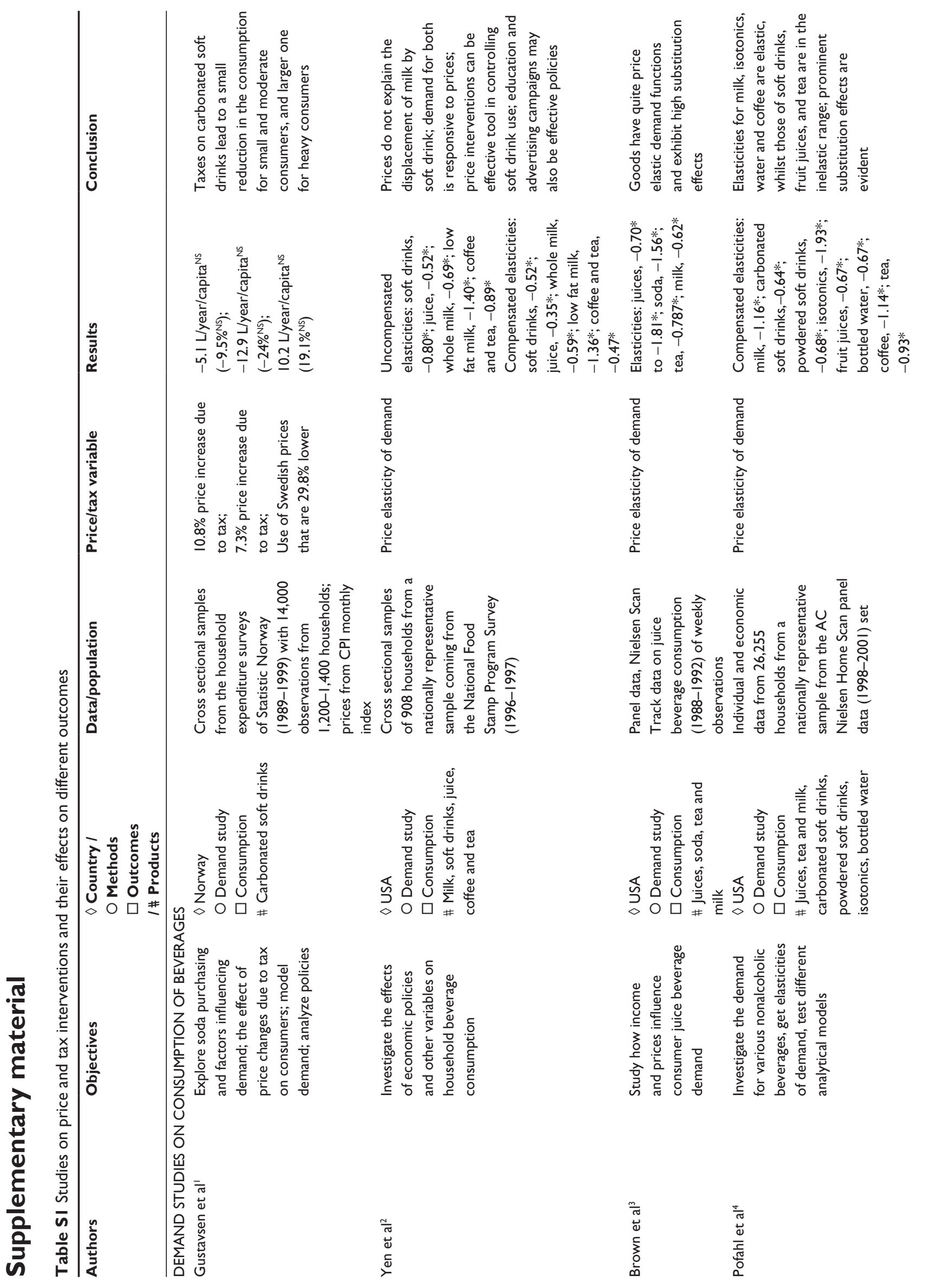



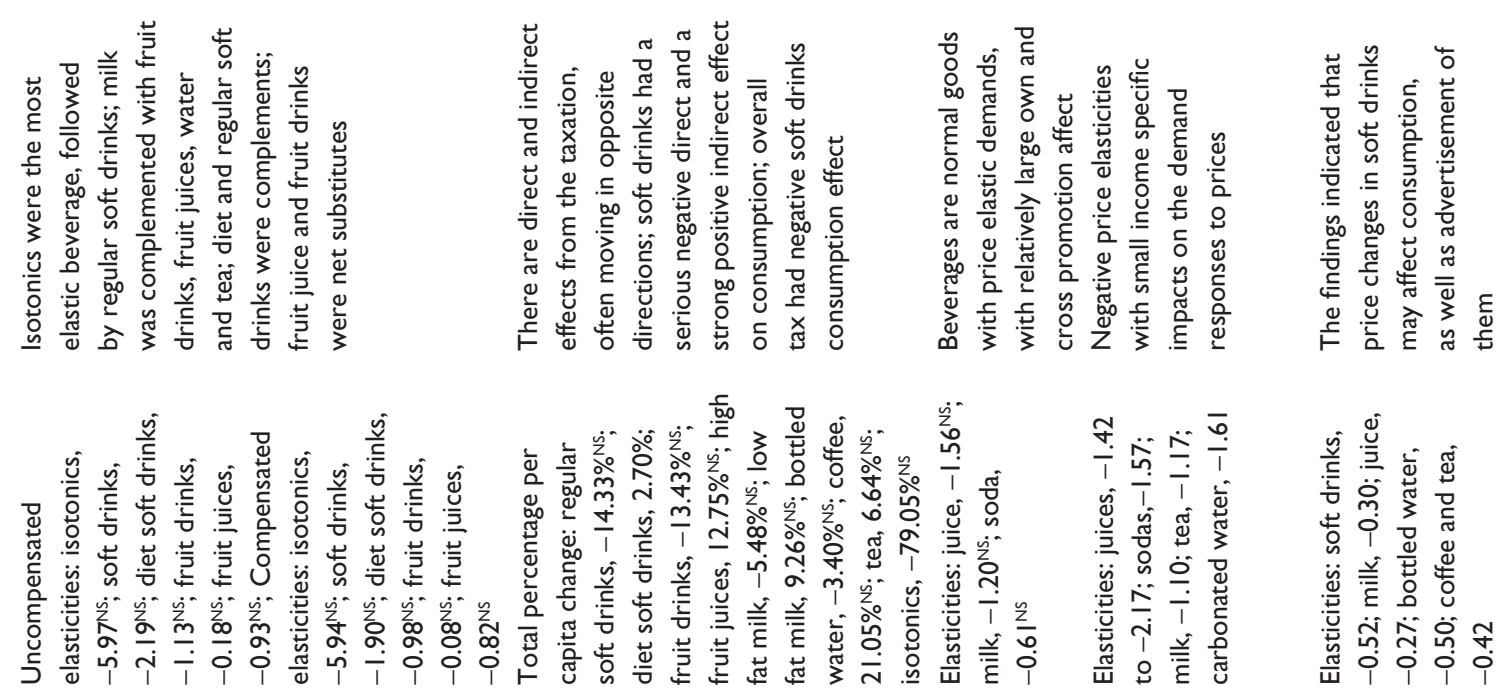
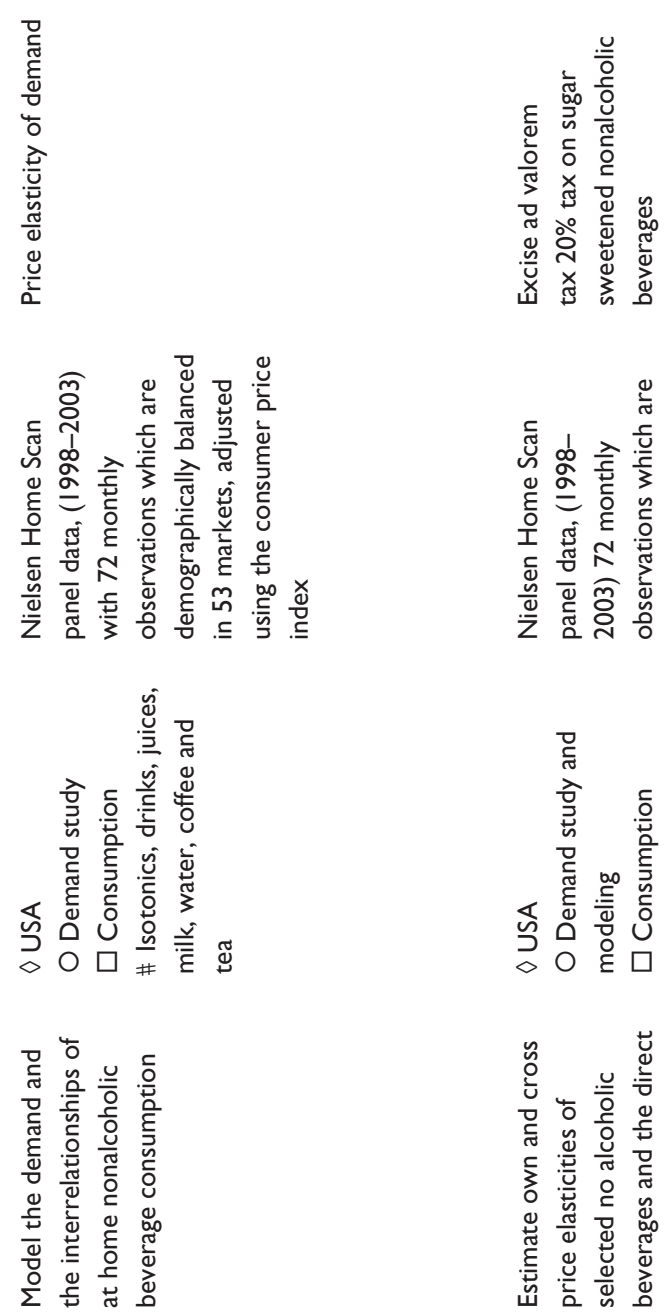

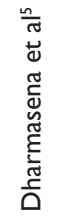
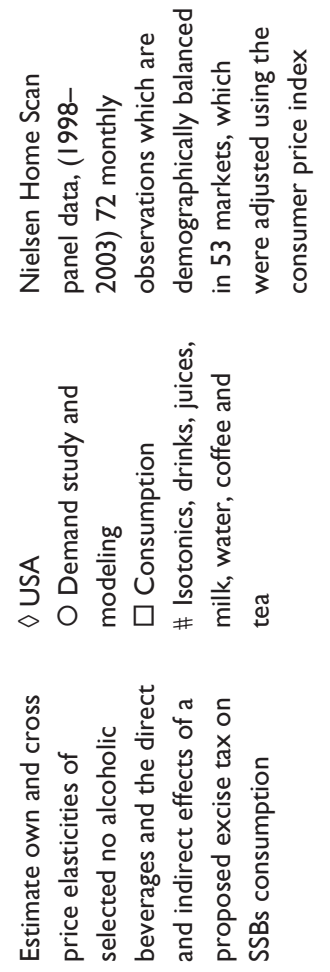

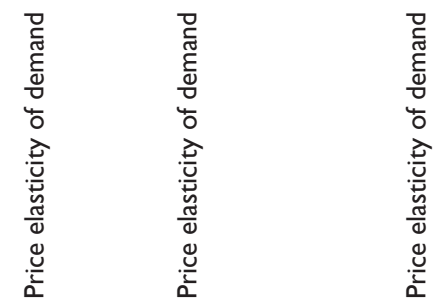

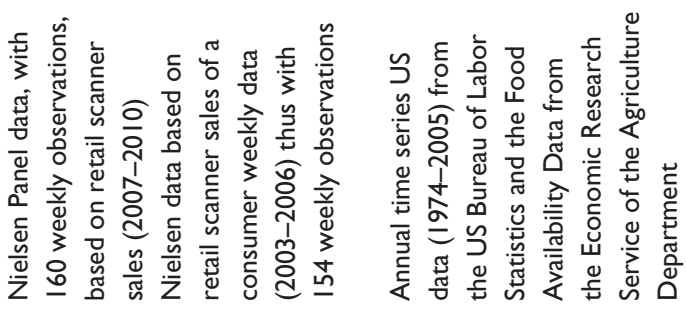
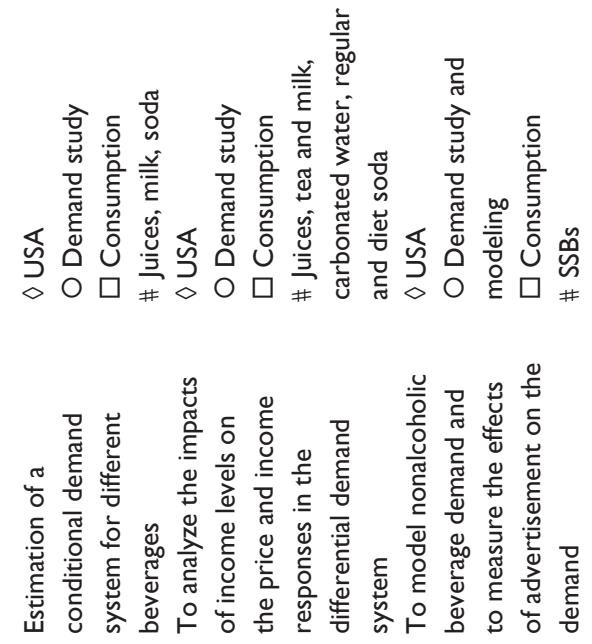


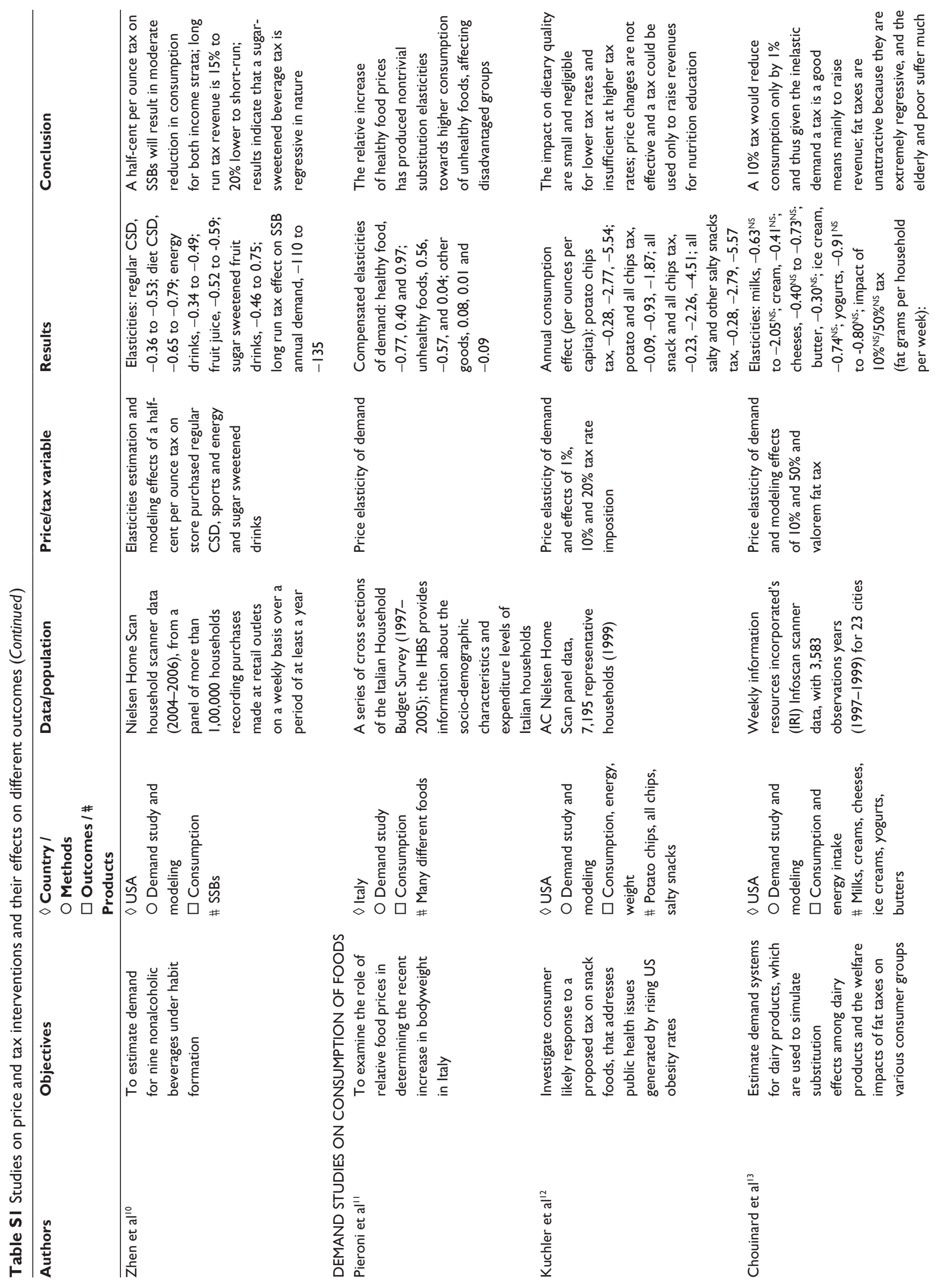




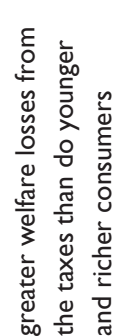
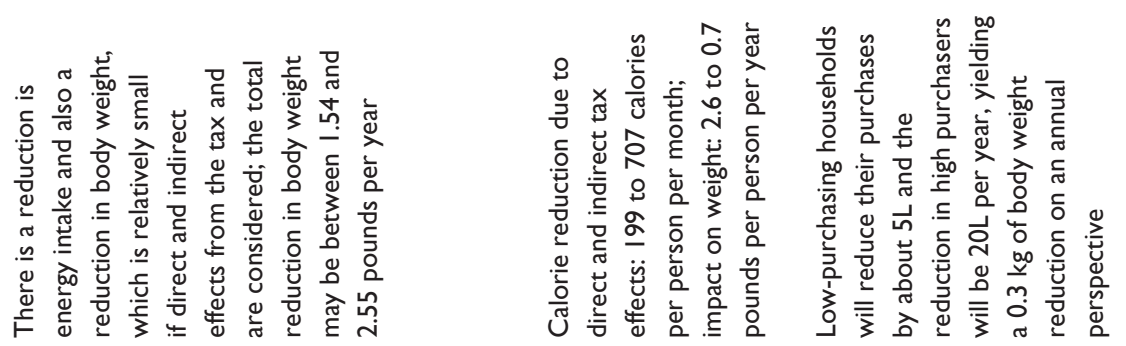

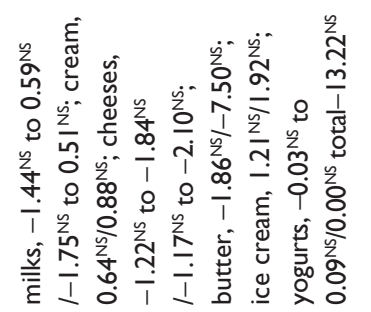

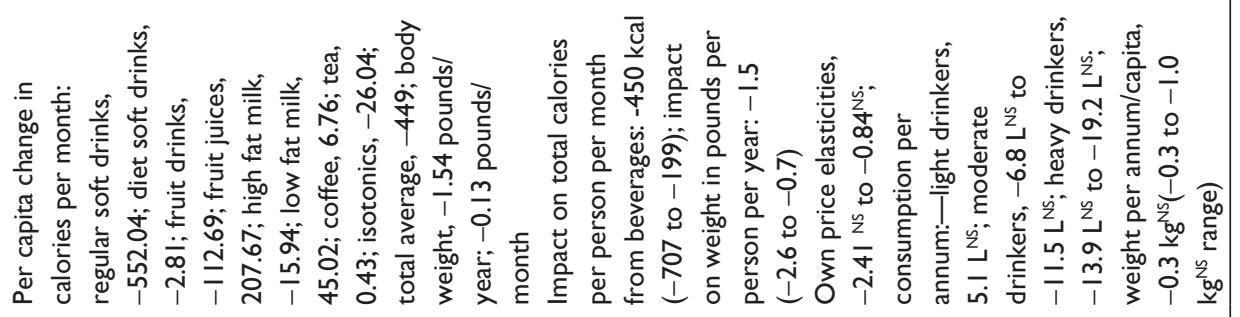

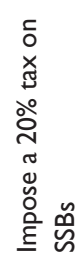

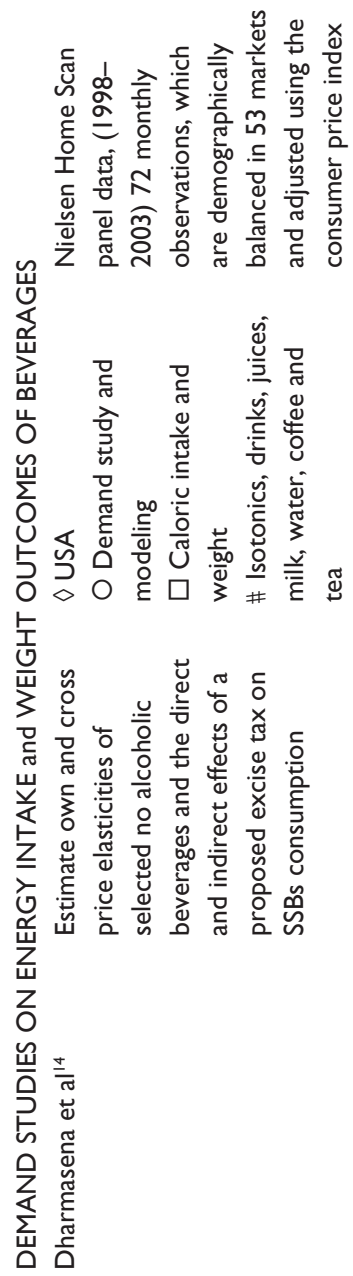

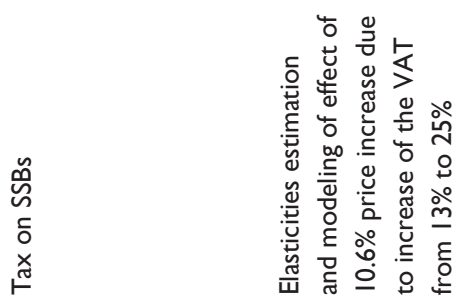
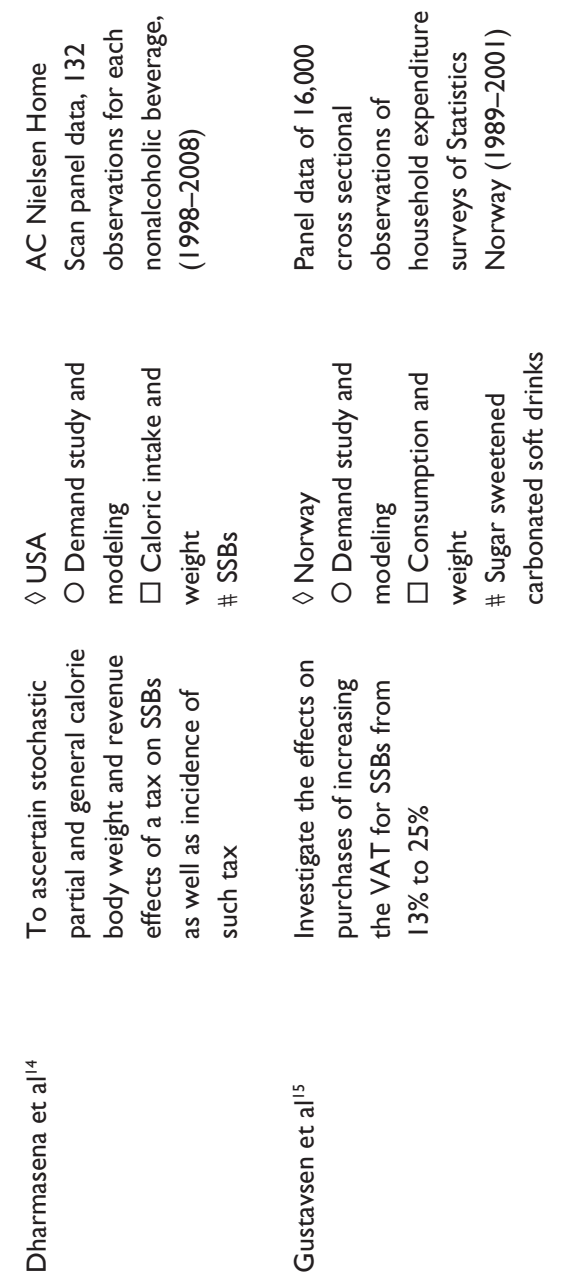


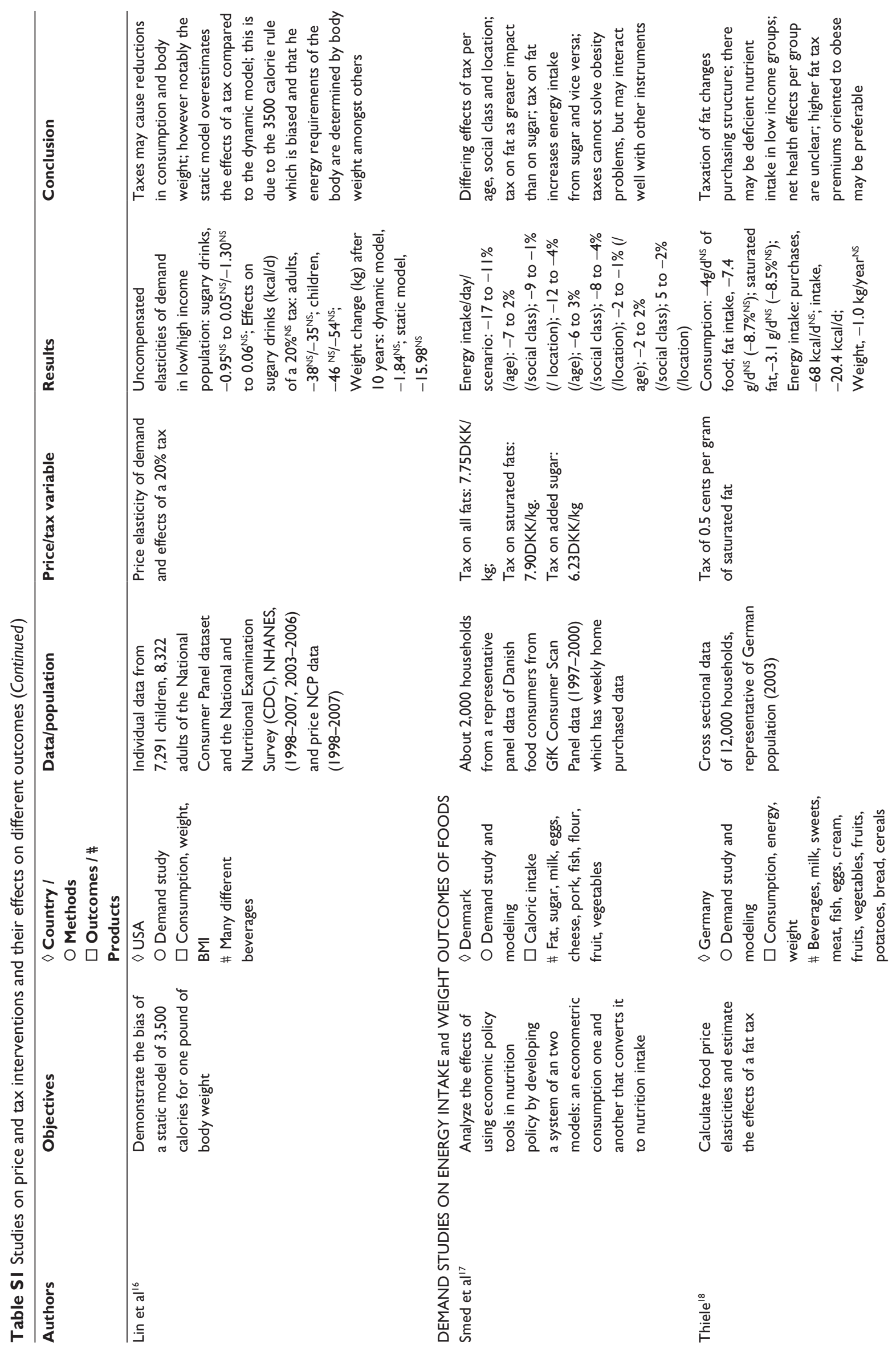




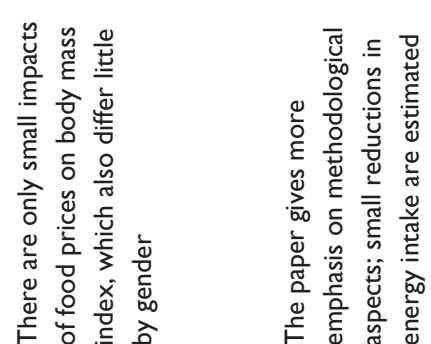

亲

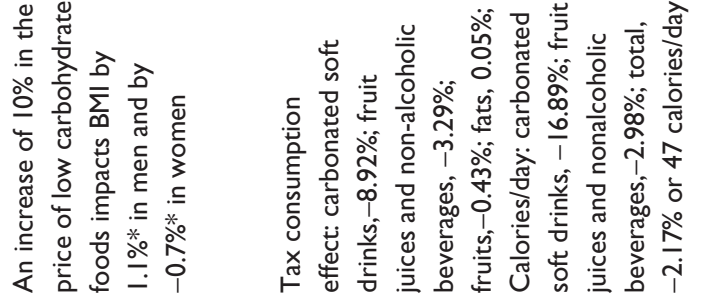

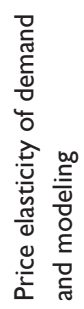

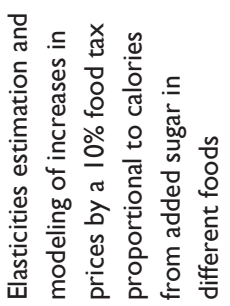

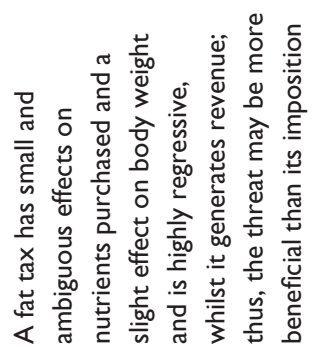

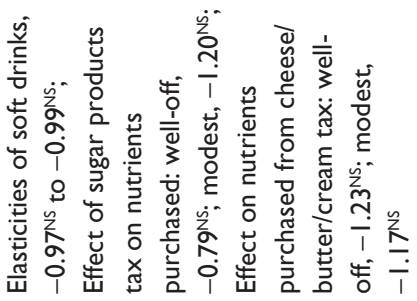
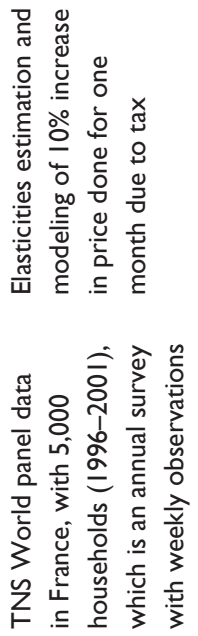

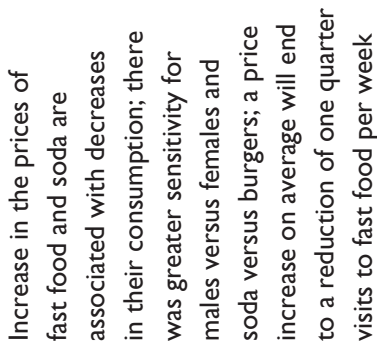

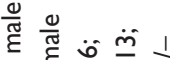

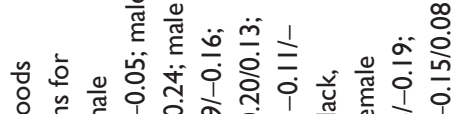

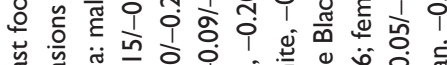

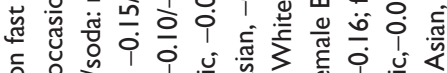

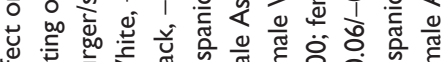

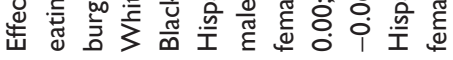

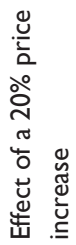

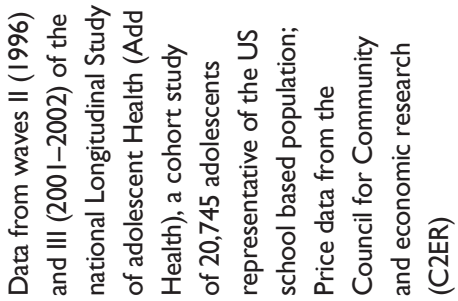

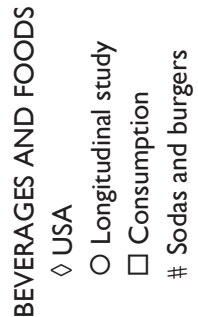

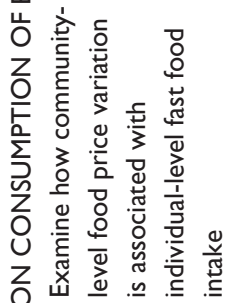

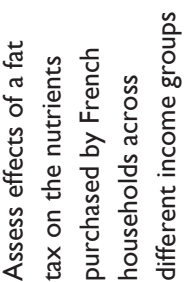

$\frac{2}{4}$

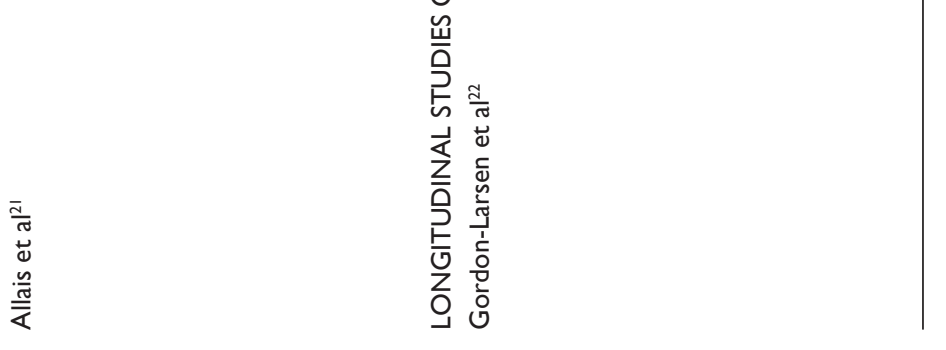




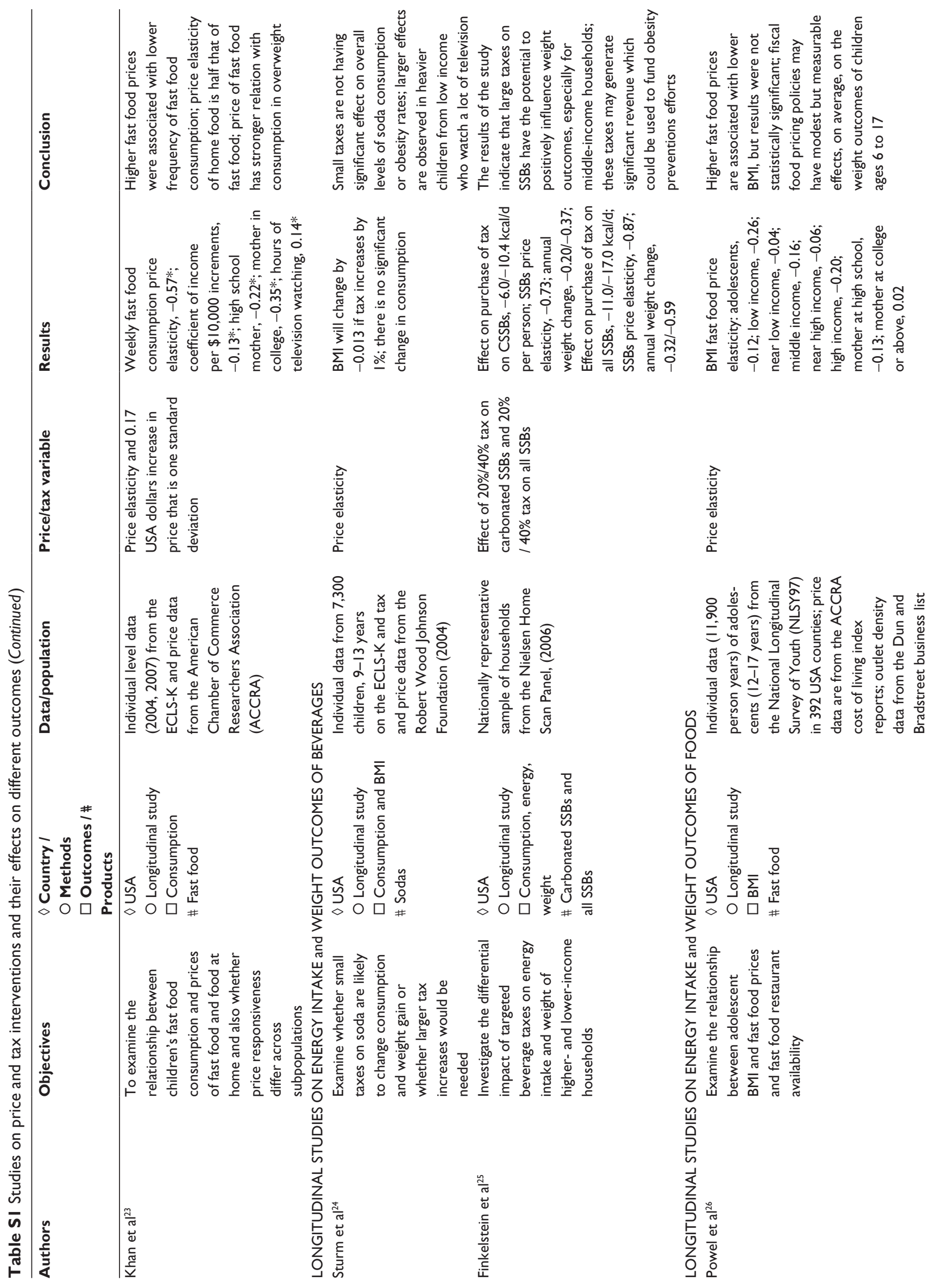




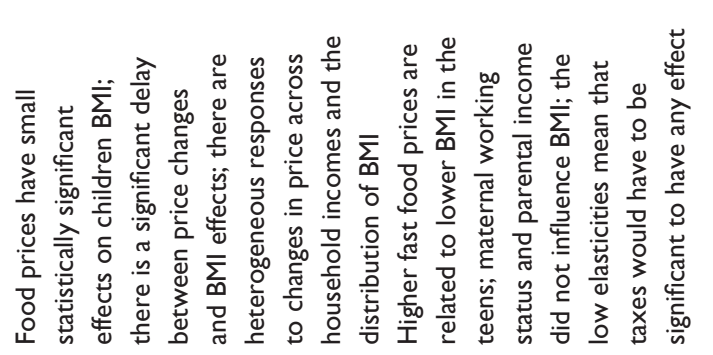
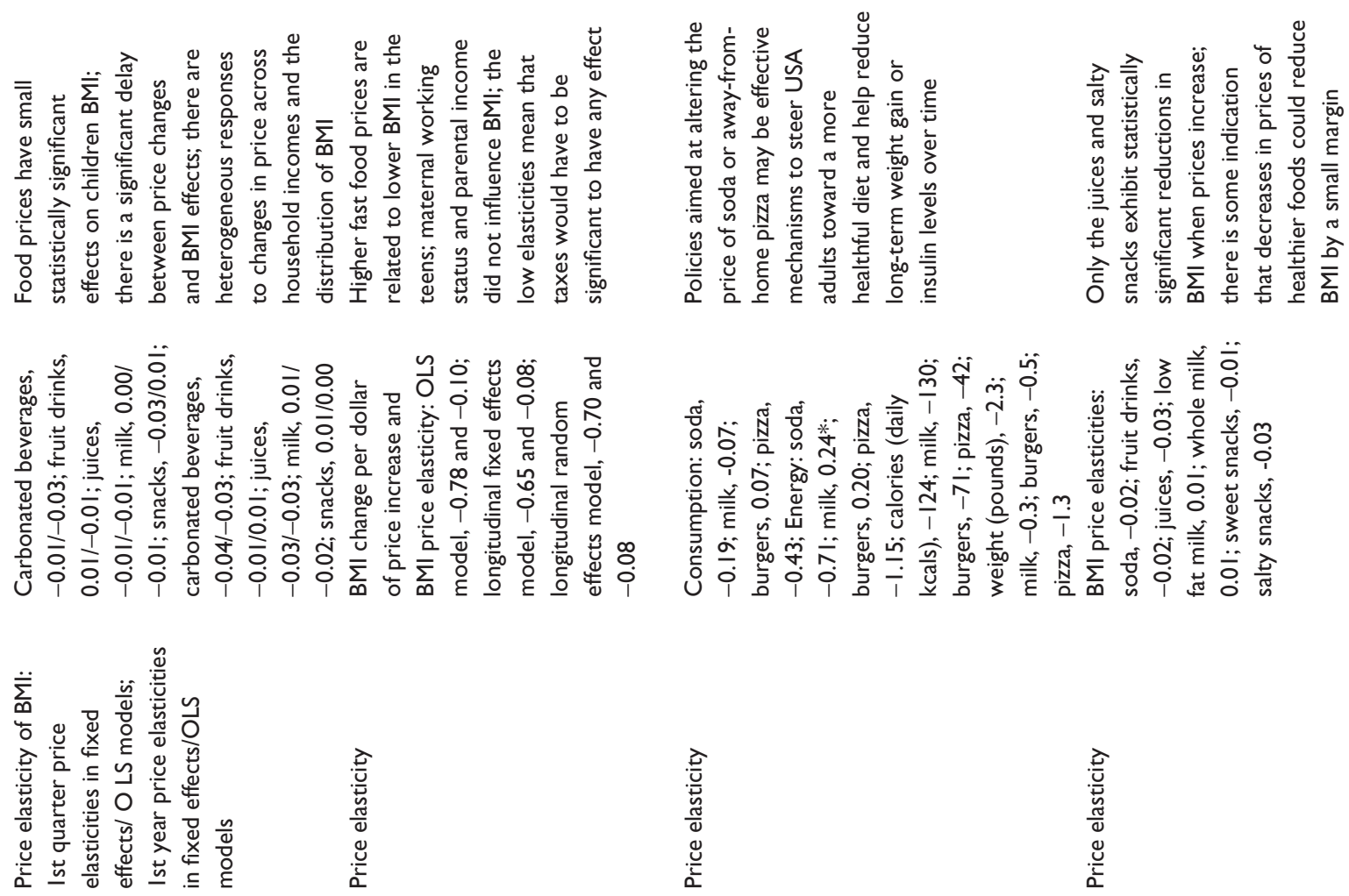

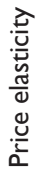
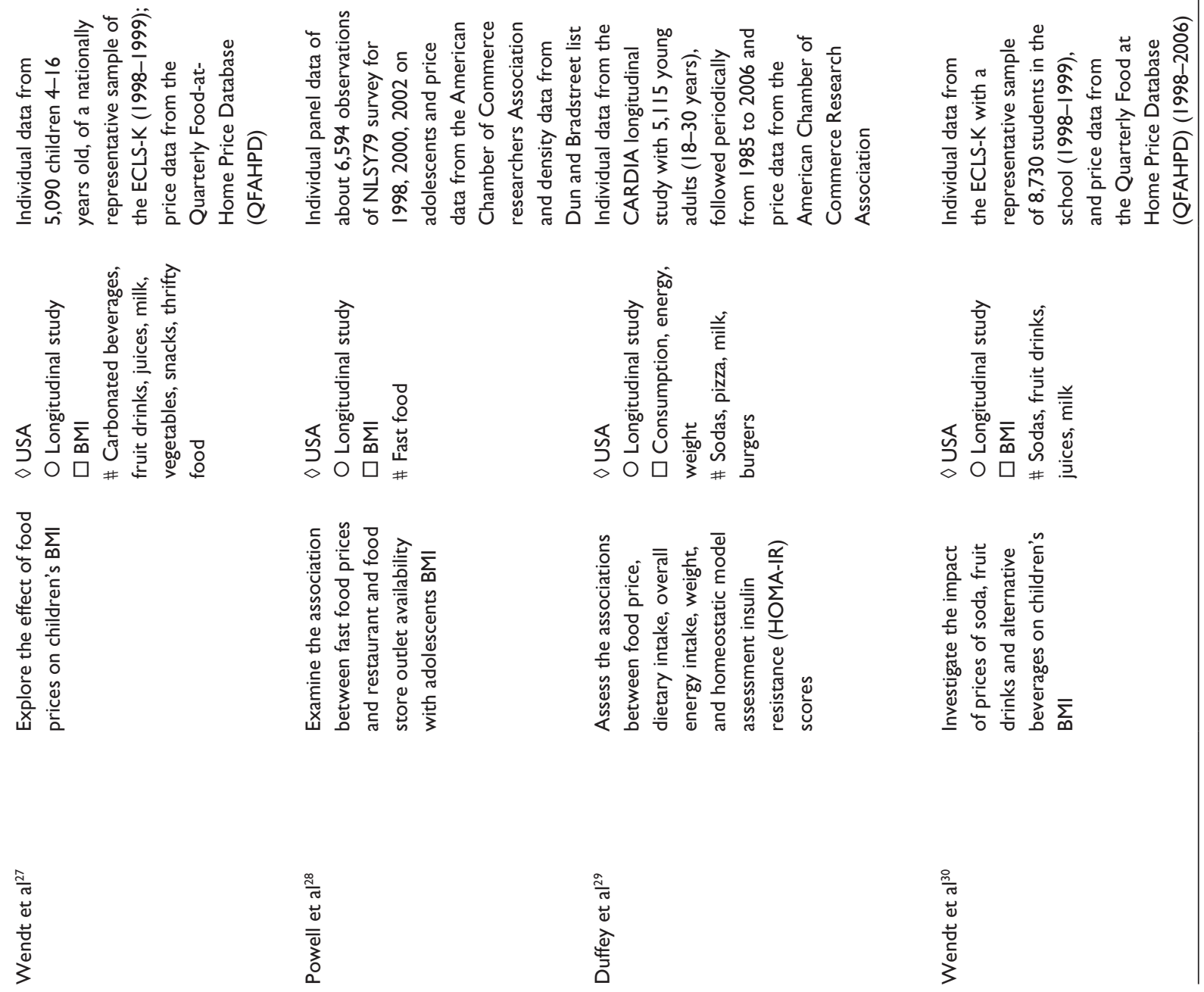

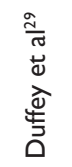

$\frac{0}{\pi}$
$\frac{0}{0}$
$\frac{0}{0}$
$\frac{0}{0}$
$\sum^{2}$ 


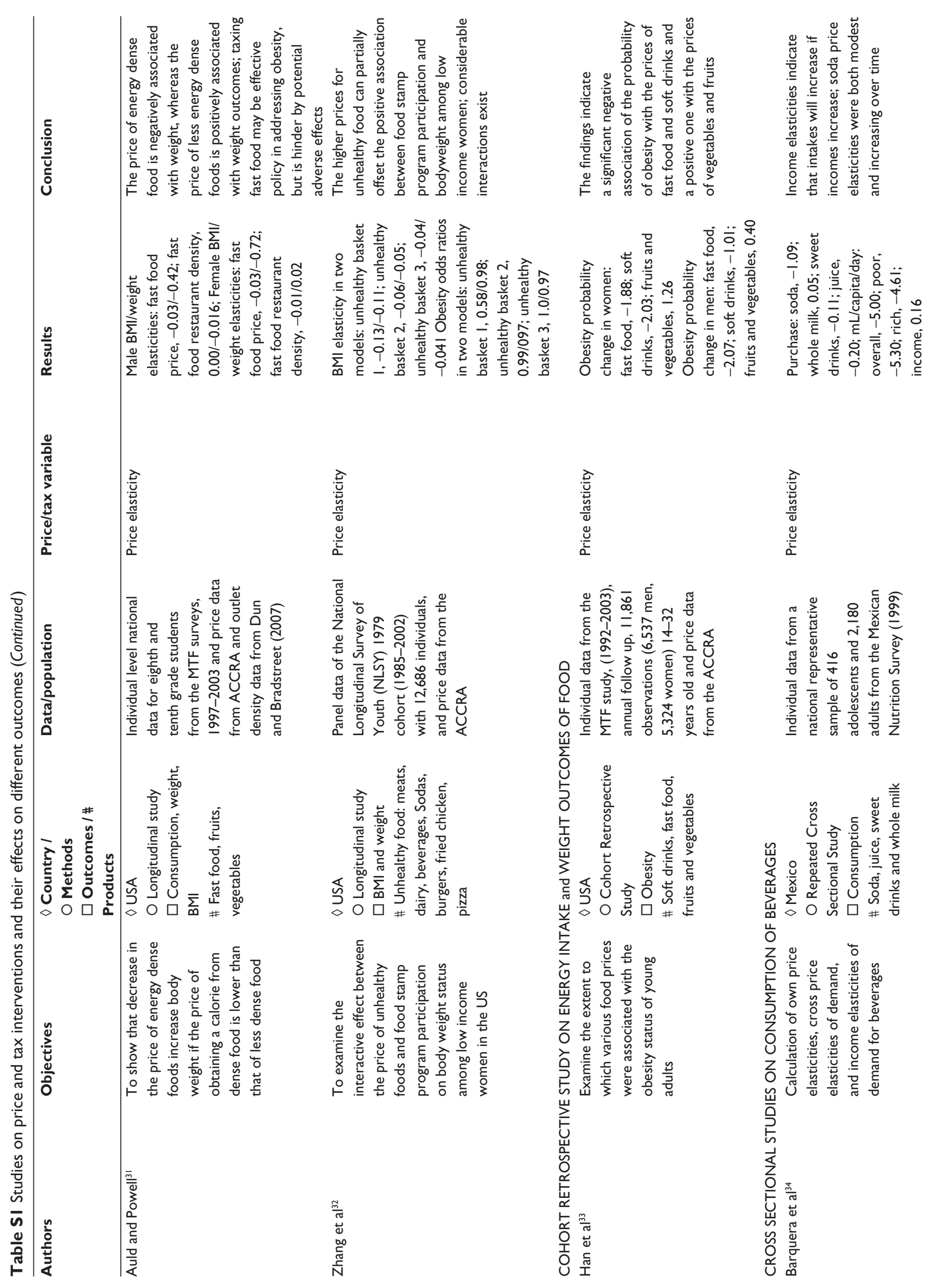



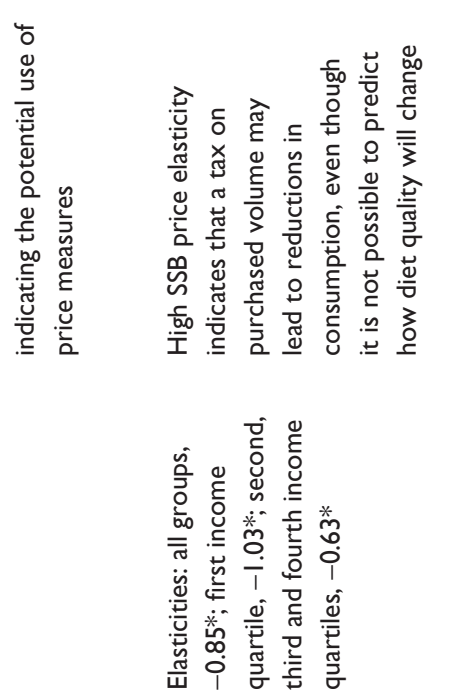
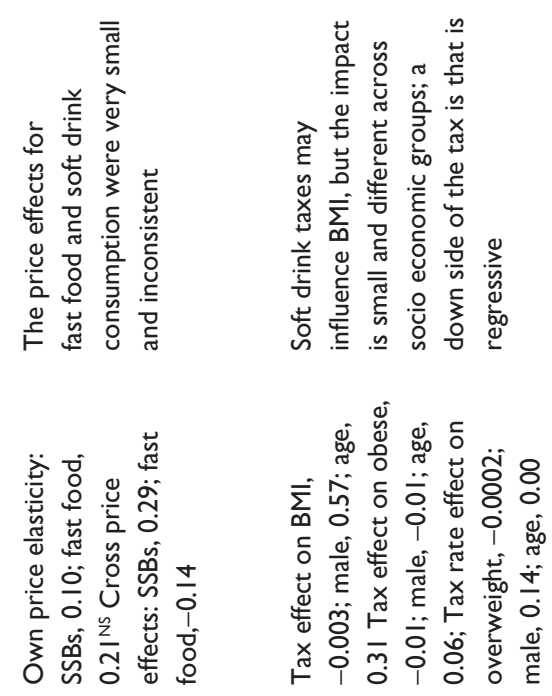
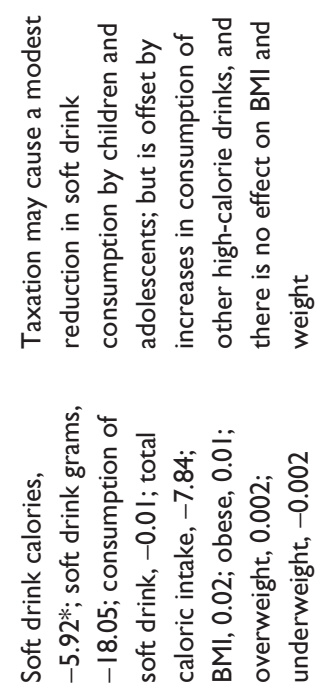

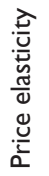

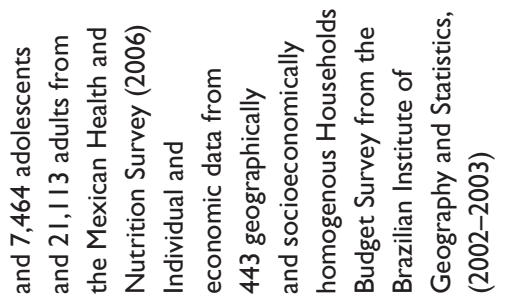

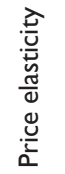

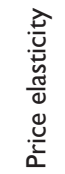

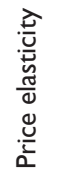

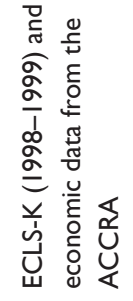
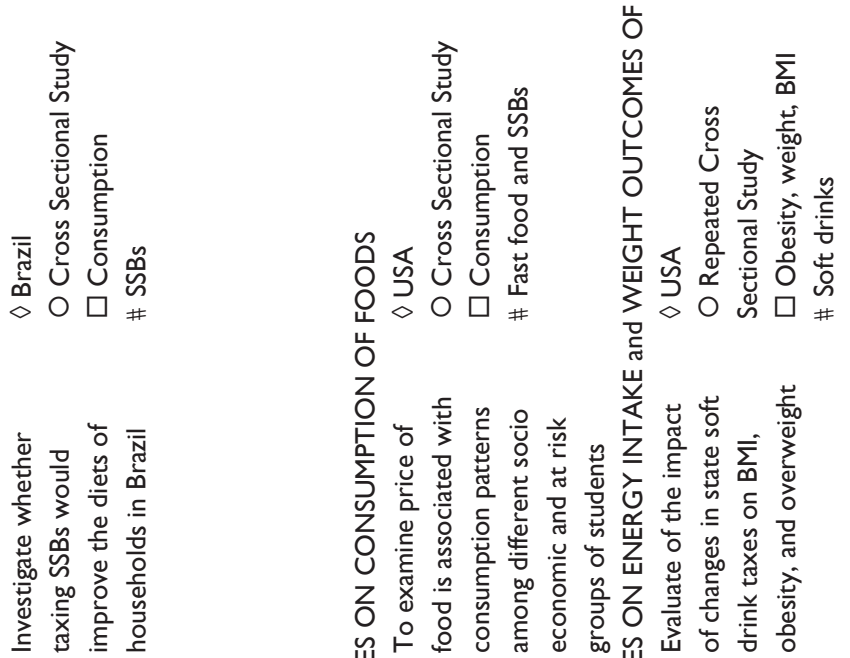

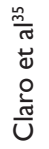
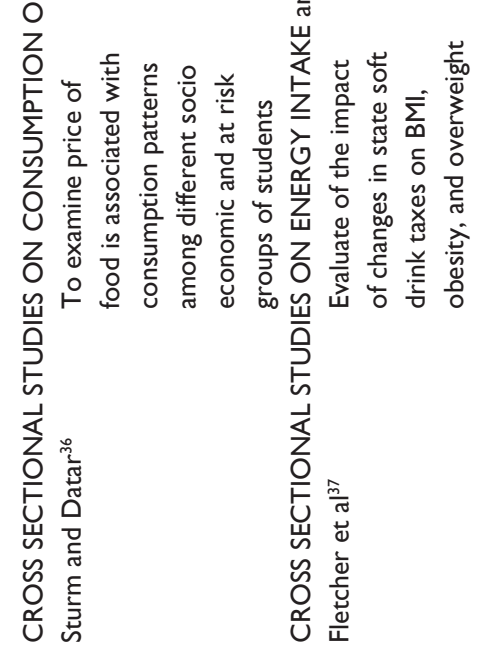
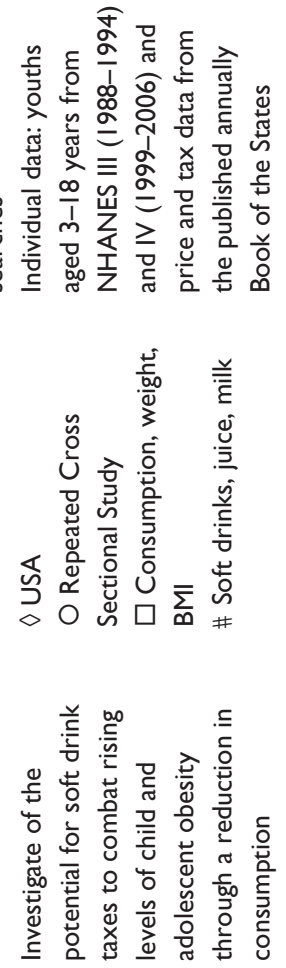


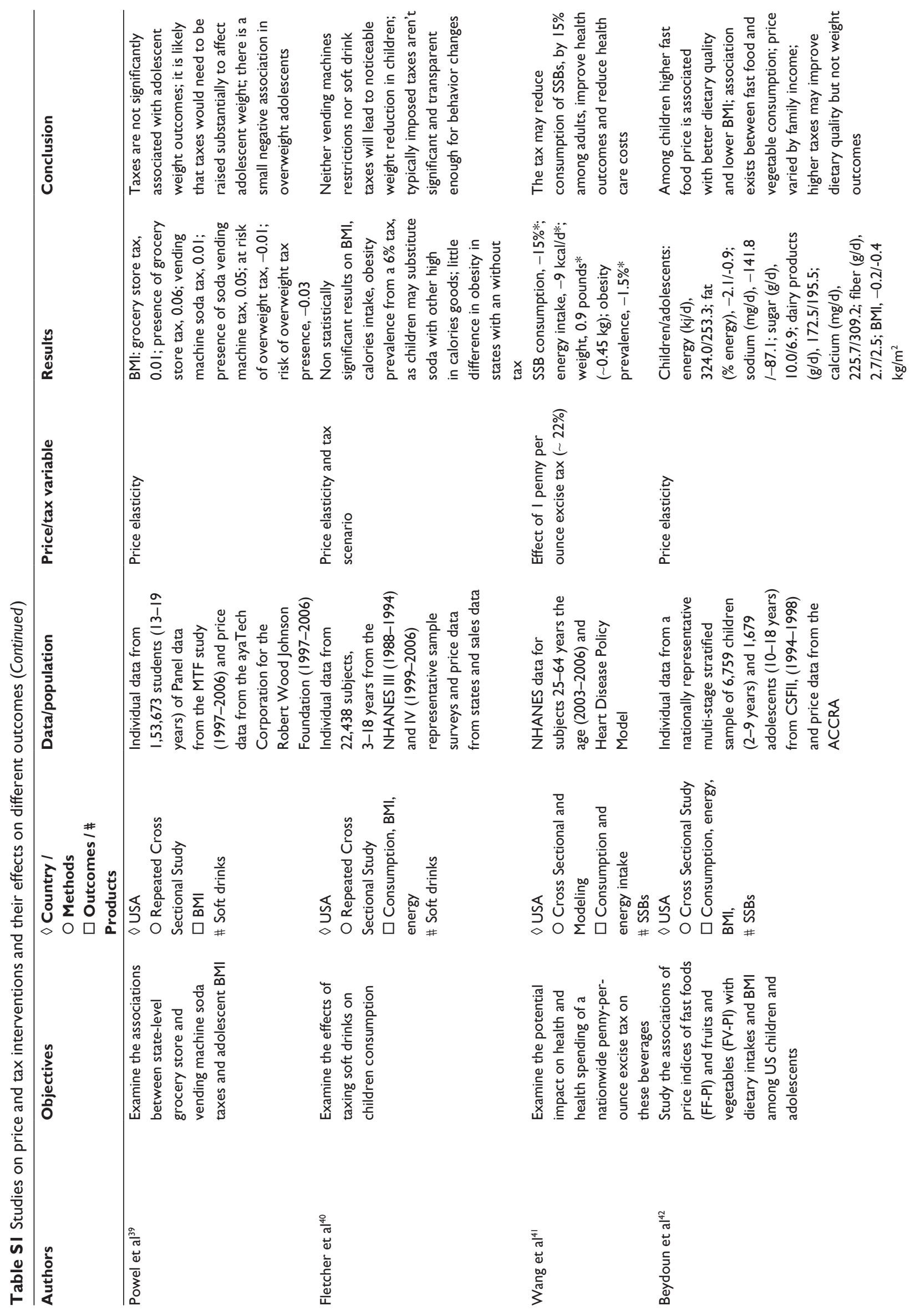




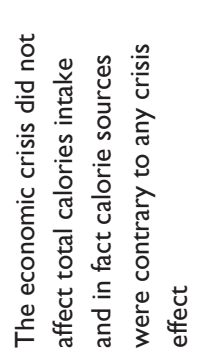

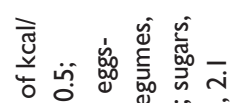

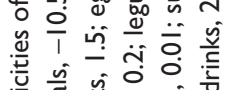

竎

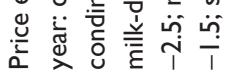

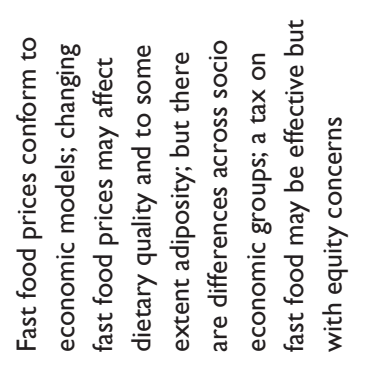

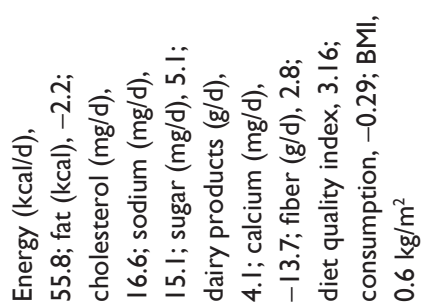

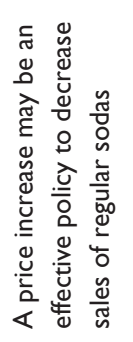

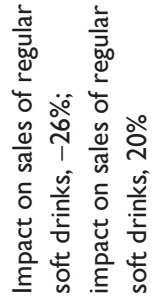

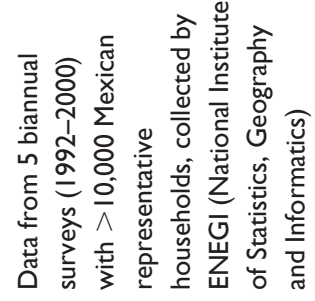

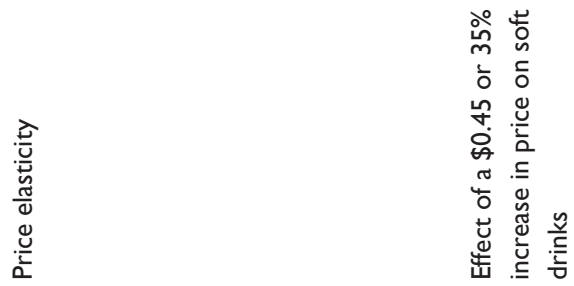

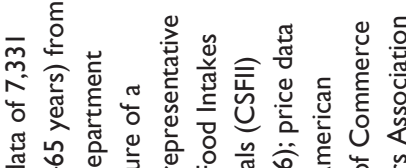

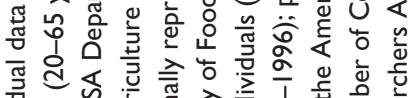

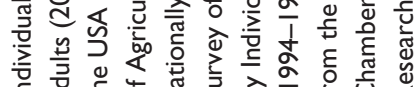

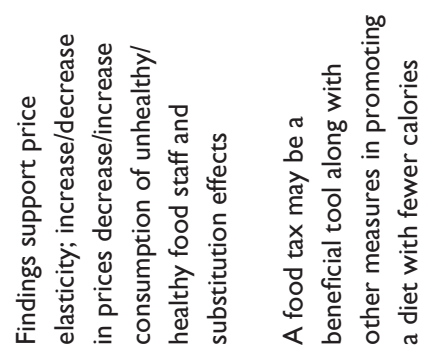

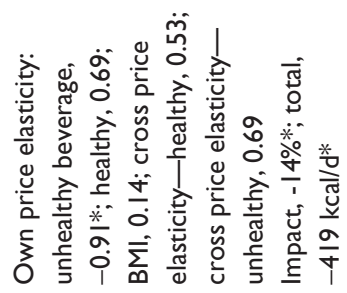
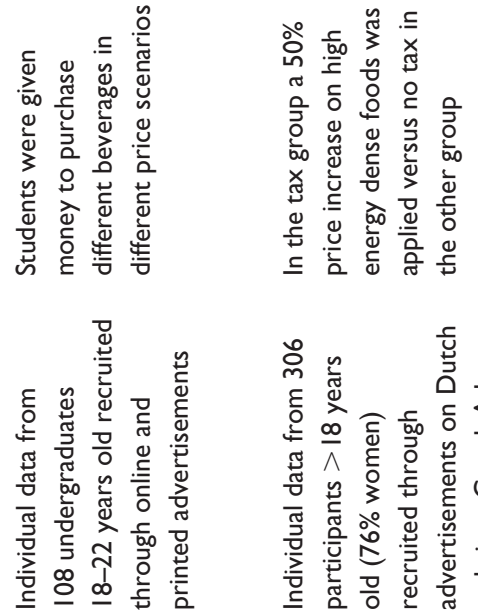

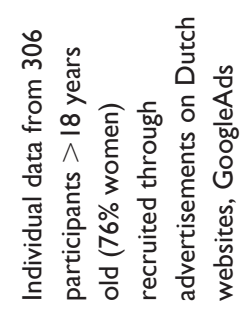

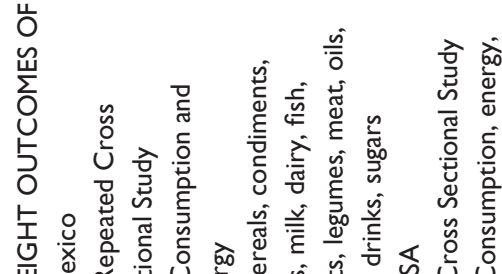

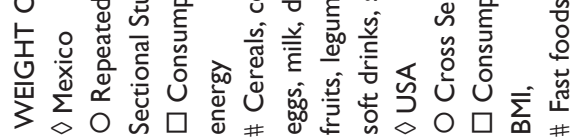
案

压

点

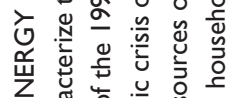

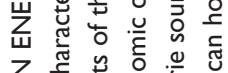

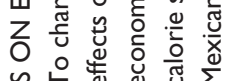

萨

至

崫

岗高

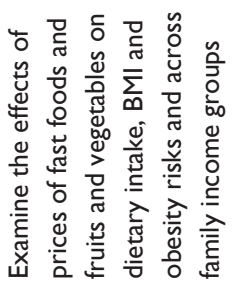

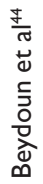

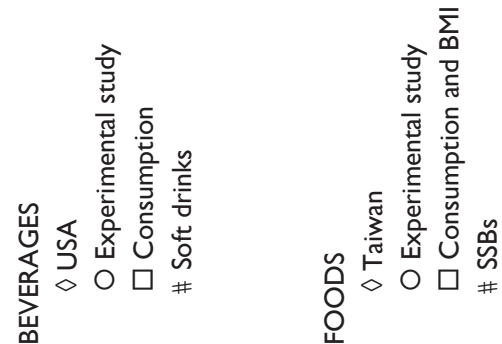

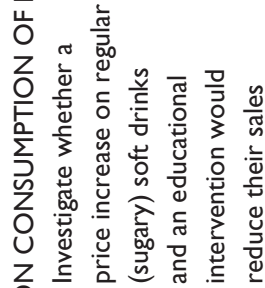

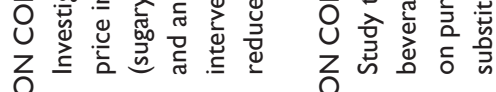

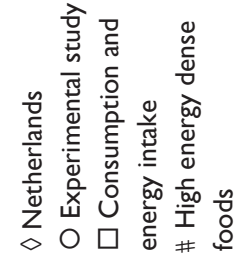

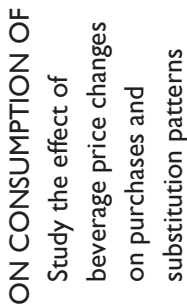

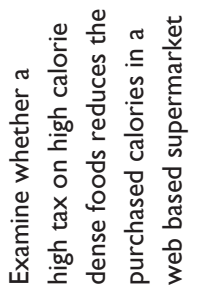

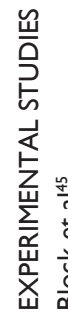

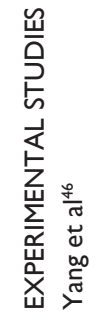




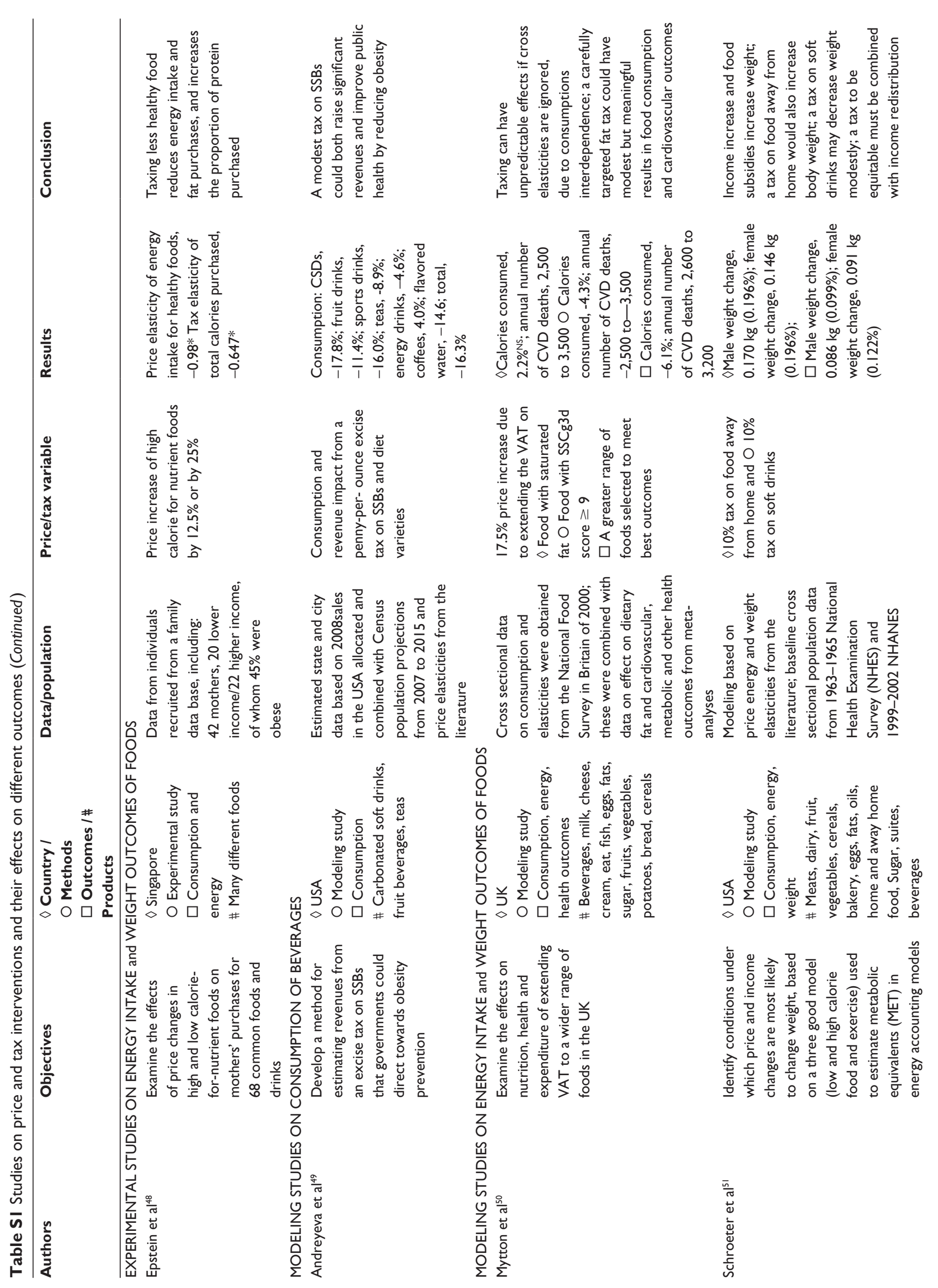



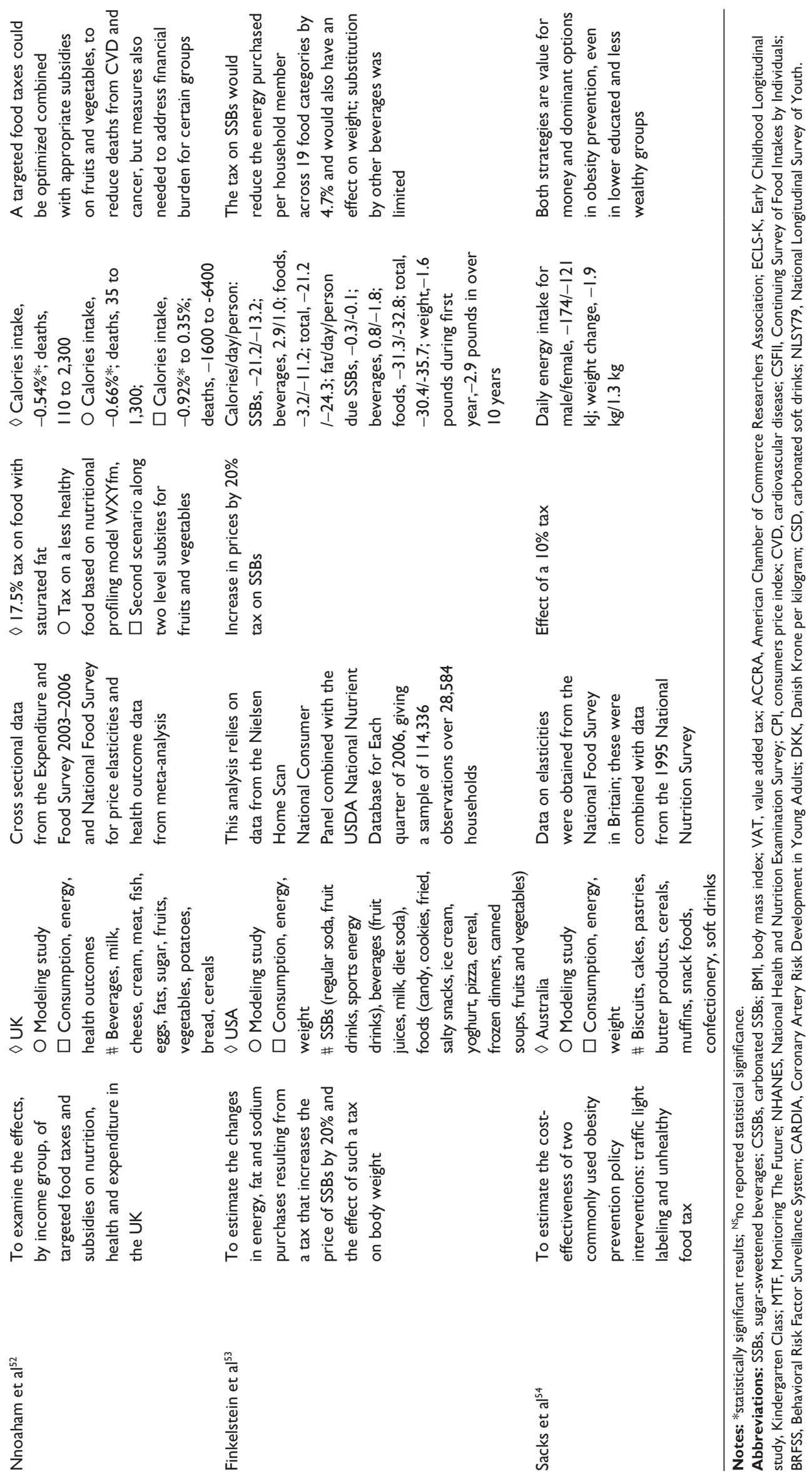

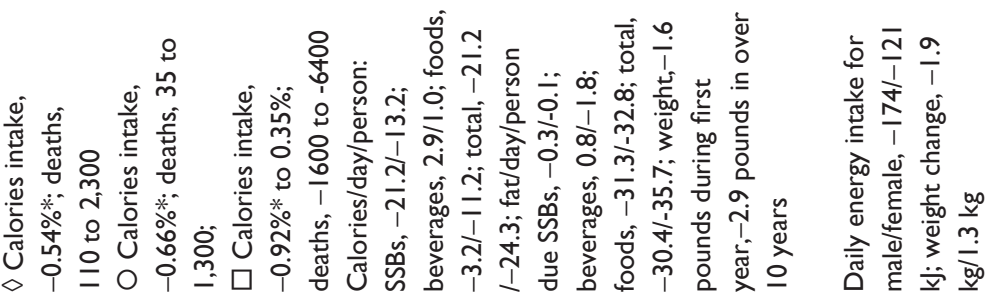

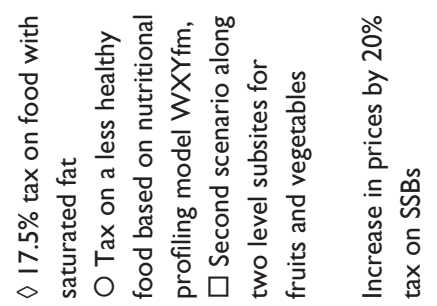

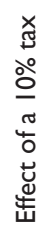

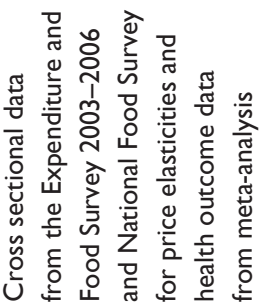

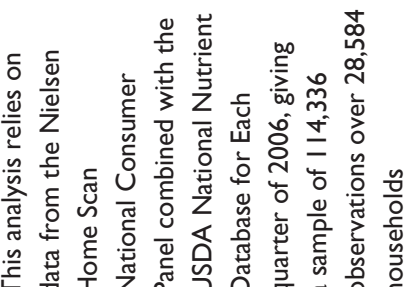

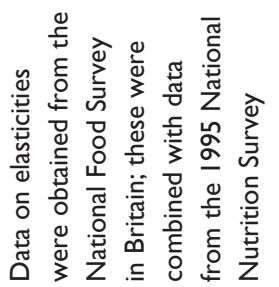

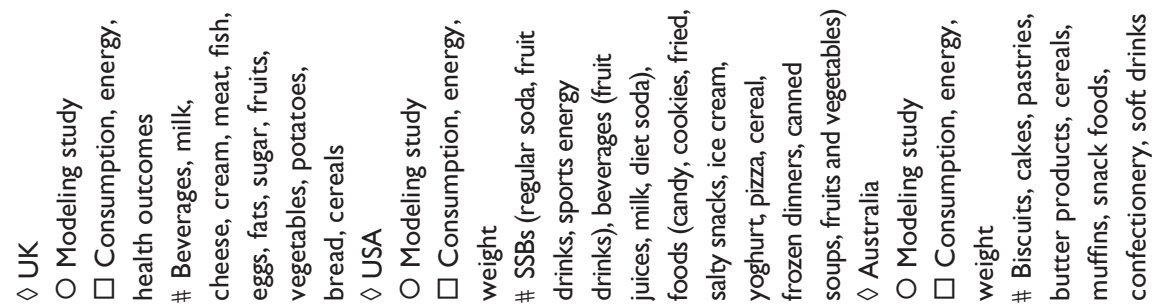
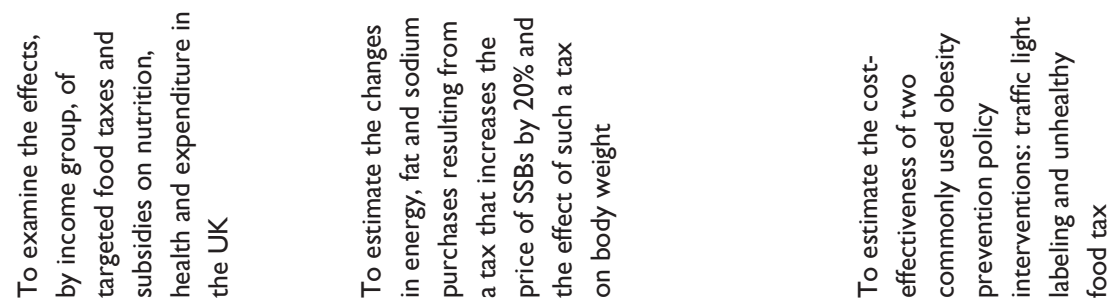

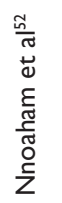

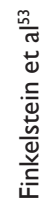

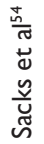

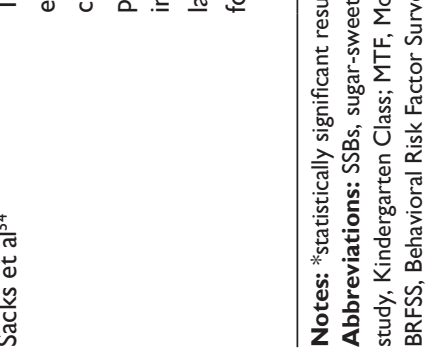




\section{References}

1. Gustavsen GW. Public policies and the demand for carbonated soft drinks: a censored quantile regression approach. Poster presented at: 11 th Congress of the European Association of Agricultural Economists; August 23-27, 2005; Copenhagen, Denmark.

2. Yen ST, Lin BH, Smallwood DM, Andrews M. Demand for nonalcoholic beverages: the case of low-income households. Agribusiness. 2004;20(3):309-321.

3. Brown MG, Lee JY, Seale JL. Demand relationships among juice beverages: a differential demand system approach. Journal of Agricultural and Applied Economics. 1994;26(2):417-429.

4. Pofahl GM, Capps O Jr, Clauson A. Demand for non-alcoholic beverages: evidence from the ACNielsen Home Scan Panel. Poster presented at: American Agricultural Economics Association Annual Meeting; July 24-27, 2005; Providence, RI.

5. Dharmasena S, Capps O Jr. Demand interrelationships of at home nonalcoholic beverage consumpion in the United States. Poster presented at: Agricultural and Applied Economics Association and American Council on Consumer Interests Joint Annual Meeting; July 28, 2009; Milwaukee, WI.

6. Dharmasena S, Capps O Jr. On taxing sugar-sweetened beverages to combat the obesity problem. Poster presented at: Agricultural and Applied Economics Association, Canadian Agricultural Economics Society, and Western Agricultural Economics Association Joint Annual Meeting; July 27, 2010; Denver, CO.

7. Brown MG, Jauregui CE. Conditional Demand System For Beverages. Gainesville, FL: Florida Department of Citrus; 2011. Available from: http://ageconsearch.umn.edu/bitstream/104335/2/RP\%202011-1.pdf. Accessed August 13, 2013.

8. Brown GM. Impact of income on price and income responses in the differential demand system. Journal of Agricultural and Applied Economics. 2008;40(2):593-608.

9. Zheng Y, Kaiser HM. Estimating assymetric advertising response: an application to US nonalcoholic beverage demand. Journal of Agricultural and Applied Economics. 2008;40(3):837-849.

10. Zhen M, Beghin JC, Jensen HH. Accounting for Product Substitution in the Analysis of Food Taxes Targeting Obesity. Ames, IA: Center for Agricultural and Rural Development; 2011. Available from: http:// www.card.iastate.edu/publications/dbs/pdffiles/10wp518.pdf. Accessed August 13, 2013.

11. Pieroni L, Lanari D, Salmasi L. Food prices and overweight patterns in Italy. Eur J Health Econ. 2013;14(1):133-151.

12. Kuchler F, Tegene A, Harris JM. Taxing snack foods: manipulating diet quality or financing information programs? Applied Economic Perspectives and Policy. 2005;27(1):4-20.

13. Chouinard HH, Davis DE, LaFrance JT, Perloff JM. Fat taxes: big money for small change. Forum Health Econ Policy. 2007;10(2): 1558-9544.

14. Dharmasena S, Capps O Jr. Intended and unintended consequences of a proposed national tax on sugar-sweetened beverages to combat the US obesity problem. Health Econ. 2012;21(6):669-694.

15. Gustavsen GW, Rickertsen K. The effects of taxes on purchases of sugar-sweetened carbonated soft drinks: a quantile regression approach. Appl Econ. 2011;43(6):707-716.

16. Lin BH, Smith TA, Lee JY, Hall KD. Measuring weight outcomes for obesity intervention strategies: the case of a sugar-sweetened beverage tax. Econ Hum Biol. 2011;9(4):329-341.

17. Smed S, Jensen JD, Denver S. Differentiated food taxes as a tool in health and nutrition policy. Poster presented at: 11th Congress of the European Association of Agricultural Economists; August 23-27, 2005; Copenhagen, Denmark.

18. Thiele S. Fat tax: a political measurement to reduce overweight? The case of Germany. Poster presented at: 1st Joint European Association of Agricultural Economists and Agricultural and Applied Economics Association Seminar; September 15-17, 2010; Freising-Weihenstephan, Germany.
19. Meyerhoefer CD, Leibtag ES. A spoonful of sugar helps the medicine go down: the relationship between food prices and medical expenditures on diabetes. Am J Agric Econ. 2010;92(5):1271-1282.

20. Zhen M, Beghin JC, Jensen HH. Accounting for Product Substitution in the Analysis of Food Taxes Targeting Obesity. Ames, IA: Center for Agricultural and Rural Development; 2011. Available from: http:// www.card.iastate.edu/publications/dbs/pdffiles/10wp518.pdf. Accessed August 13, 2013.

21. Allais O, Bertail P, Nichele V. The effects of a "fat tax" on the nutrient intake of French households. Poster presented at: 12th Congress of the European Association of Agricultural Economists; August 26-29, 2008; Ghent, Belgium.

22. Gordon-Larsen P, Guilkey DK, Popkin BM. An economic analysis of community-level fast food prices and individual-level fast food intake: a longitudinal study. Health Place. 2011;17(6):1235-1241.

23. Khan LK, Sobush K, Keener D, et al. Recommended community strategies and measurements to prevent obesity in the United States. MMWR Recomm Rep. 2009;58(RR-7):1-26.

24. Sturm R, Powell LM, Chriqui JF, Chaloupka FJ. Soda taxes, soft drink consumption, and children's body mass index. Health Aff (Millwood). 2010;29(5):1052-1058.

25. Finkelstein EA, Zhen C, Nonnemaker J, Todd JE. Impact of targeted beverage taxes on higher- and lower-income households. Arch Intern Med. 2010;170(22):2028-2034.

26. Powell LM. Fast food costs and adolescent body mass index: evidence from panel data. J Health Econ. 2009;28(5):963-970.

27. Wendt M, Todd JE. The Effect of Food and Beverage Prices on Children's Weights. Washington, DC: US Department of Agriculture; 2011. Available from: http://www.ers.usda.gov/media/123670/err118.pdf. Accessed August 13, 2013.

28. Powell LM, Chaloupka FJ. Food prices and obesity: evidence and policy implications for taxes and subsidies. Milbank $Q$. 2009;87(1):229-257.

29. Duffey KJ, Gordon-Larsen P, Shikany JM, Guilkey D, Jacobs DR Jr, Popkin BM. Food price and diet and health outcomes: 20 years of the CARDIA Study. Arch Intern Med. 2010;170(5):420-426.

30. Wendt M, Todd JE. Do low prices for sugar-sweetened beverages increase children's weights? Poster presented at: Agricultural and Applied Economics Association, Canadian Agricultural Economics Society, and Western Agricultural Economics Association Joint Annual Meeting; July 27, 2010; Denver, CO.

31. Auld CM, Powell LM. Economics of food energy density and adolescent body weight. Economica. 2009;76(304):719-740.

32. Zhang Q, Chen Z, Diawara N, Wang Y. Prices of unhealthy foods, food stamp program participation, and body weight status among US lowincome women. J Fam Econ Issues. 2011;32(2):245-256.

33. Han E, Powell LM. Effect of food prices on the prevalence of obesity among young adults. Public Health. 2011;125(3):129-135.

34. Barquera S, Hernandez-Barrera L, Tolentino ML, et al. Energy intake from beverages is increasing among Mexican adolescents and adults. J Nutr. 2008;138(12):2454-2461.

35. Claro RM, Levy RB, Popkin BM, Monteiro CA. Sugar-sweetened beverage taxes in Brazil. Am J Public Health. 2012;102(1): $178-183$.

36. Sturm R, Datar A. Regional price differences and food consumption frequency among elementary school children. Public Health. 2011;125(3):136-141.

37. Fletcher JM, Frisvold D, Tefft N. Can soft drink taxes reduce population weight? Contemp Econ Policy. 2010;28(1):23-35.

38. Fletcher JM, Frisvold DE, Tefft N. The effects of soft drink taxes on child and adolescent consumption and weight outcomes. J Public Econ. 2010;94(11-12):967-974.

39. Powell LM, Zhao Z, Wang Y. Food prices and fruit and vegetable consumption among young American adults. Health Place. 2009;15(4): 1064-1070. 
40. Fletcher JM, Frisvold D, Tefft N. Taxing soft drinks and restricting access to vending machines to curb child obesity. Health Aff (Millwood). 2010;29(5):1059-1066.

41. Wang YC, Coxson P, Shen YM, Goldman L, Bibbins-Domingo K. A penny-per-ounce tax on sugar-sweetened beverages would cut health and cost burdens of diabetes. Health Aff (Millwood). 2012;31(1): 199-207.

42. Beydoun MA, Powell LM, Chen X, Wang Y. Food prices are associated with dietary quality, fast food consumption, and body mass index among US children and adolescents. J Nutr. 2011;141(2):304-311.

43. Arroyo P, Loria A, Mendez O. Changes in the household calorie supply during the 1994 economic crisis in Mexico and its implications on the obesity epidemic. Nutr Rev. 2004;62(7 Pt 2):S163-S168.

44. Beydoun MA, Powell LM, Wang Y. The association of fast food, fruit and vegetable prices with dietary intakes among US adults: is there modification by family income? Soc Sci Med. 2008;66(11):2218-2229.

45. Block JP, Chandra A, McManus KD, Willet WC. Point-of-purchase price and education intervention to reduce consumption of sugary soft drinks. Am J Public Health. 2010;100(8):1427-1433.

46. Yang CC, Chiou WB. Substitution of healthy for unhealthy beverages among college students. A health-concerns and behavioral-economics perspective. Appetite. 2010;54(3):512-516.

47. Nederkoorn C, Havermans RC, Giesen JC, Jansen A. High tax on high energy dense foods and its effects on the purchase of calories in a supermarket. An experiment. Appetite. 2011;56(3):760-765.
48. Epstein LH, Dearing KK, Roba LG, Finkelstein E. The influence of taxes and subsidies on energy purchased in an experimental purchasing study. Psychol Sci. 2010;21(3):406-414.

49. Andreyeva T, Chaloupka FJ, Brownell KD. Estimating the potential of taxes on sugar-sweetened beverages to reduce consumption and generate revenue. Prev Med. 2011;52(6):413-416.

50. Mytton O, Gray A, Rayner M, Rutter H. Could targeted food taxes improve health? J Epidemiol Community Health. 2007;61(8):689-694.

51. Schroeter C, Lusk J, Tyner W. Determining the impact of food price and income changes on body weight. J Health Econ. 2008;27(1):45-68.

52. Nnoaham KE, Sacks G, Rayner M, Mytton O, Gray A. Modelling income group differences in the health and economic impacts of targeted food taxes and subsidies. Int J Epidemiol. 2009;38(5):1324-1333.

53. Finkelstein EA, Zhen C, Bilger M, Nonnemaker J, Farooqui AM, Todd JE. Implications of a sugar-sweetened beverage (SSB) tax when substitutions to non-beverage items are considered. $J$ Health Econ. 2013;32(1):219-239.

54. Sacks G, Veerman JL, Moodie M, Swinburn B. "Traffic-light" nutrition labelling and "junk-food" tax: a modelled comparison of costeffectiveness for obesity prevention. Int J Obes (Lond). 2011;35(7): 1001-1009.
ClinicoEconomics and Outcomes Research

\section{Publish your work in this journal}

ClinicoEconomics \& Outcomes Research is an international, peerreviewed open-access journal focusing on Health Technology Assessment, Pharmacoeconomics and Outcomes Research in the areas of diagnosis, medical devices, and clinical, surgical and pharmacological intervention. The economic impact of health policy and health systems

\section{Dovepress}

organization also constitute important areas of coverage. The manuscript management system is completely online and includes a very quick and fair peer-review system, which is all easy to use. Visit http://www.dovepress.com/testimonials.php to read real quotes from published authors. 